\title{
HUELLAS DE LA ANTIGÜEDAD EN LA HERNANDIA, DE FRANCISCO RUIZ DE LEÓN
}

\section{Contexto y FORTuna DE la HeRNANDIA}

\section{Cuestiones biográfico-literarias}

La presencia del poeta novohispano Francisco Ruiz de León en las historias de la literatura suele limitarse a una referencia sucinta al poema heroico Hernandia, su obra principal ${ }^{1}$, y a los hitos biográficos aportados a principios del siglo xıx por don José Mariano Beristáin de Souza y que deberían ser rectificados a la luz de investigaciones más recientes ${ }^{2}$. En efecto, aunque según el erudito,

1 Así, Marcelino Menéndez Pelayo, Historia de la poesía hispanoamericana, Victoriano Suárez, Madrid, 1911, t. 1, pp. 80-81 y Margarita PeÑa, "Poesía épica”, en Historia de la literatura hispanoamericana. T. 1: Del descubrimiento al modernismo, eds. R. González Echevarría y E. Pupo-Walker, Gredos, Madrid, 2006, pp. 274-275 (= The Cambridge history of Latin American literature, Cambridge University Press, 1996, t. 1, pp. 254-255). Razones cronológicas explicarían su ausencia en la monografía de Frank Pierce, La poesía épica del Siglo de Oro, $2^{\mathrm{a}}$ ed., Gredos, Madrid, 1968, pero tampoco figura entre los autores del XVIII mencionados por Pedro Piñero Ramírez, "La épica hispanoamericana colonial", en Luis Íñigo Madrigal, Historia de la literatura hispanoamericana. T. 1: Época colonial, 5 a ed., Cátedra, Madrid, 2008, pp. 161-188 y por JuAn BAUTiSTA DE Avalle-Arce, La épica colonial, Universidad de Navarra, Pamplona, 2000.

${ }^{2}$ En Biblioteca hispanoamericana septentrional, t. 2, México, 1816-1819, información resumida en Diccionario universal de historia y de geografía, t. 6, s.v. "Ruiz de León (D. Francisco)", Librería de Andrade, México, 1855, p. 705 [digitalizado en http:// books.google.com]. A Beristáin remite MARGARITA PEÑA en "Poesía épica..." y en "Luces dieciochescas sobre la conquista de México: la crónica rimada de Ruiz de León”, Noesis, 8 (1992), 121-123. Para la actualización de la biografía véanse: EnriQue Cordero y Torres, Diccionario biográfico de Puebla, Centro de Estudios Históricos, Puebla, 1973, t. 2, pp. 608-609; Diccionario Porrúa de historia, biografía y geografía de México, $3^{\mathrm{a}}$ ed., Porrúa, México, 1976, t. 2, p. 1819, citando dos ensayos de Salvador Cruz: 
Ruiz de León vio la luz el año 1683 en Tehuacán de las Granadas, su partida de bautismo testimonia que era nacido en Puebla de los Ángeles ${ }^{3}$. Tras estudiar humanidades en el poblano Colegio de San Jerónimo, filosofía en la Ciudad de México y teología en el Colegio de San Ignacio de Puebla, se graduó de bachiller, pese a lo cual no profesó en religión sino que contrajo dos veces matrimonio ${ }^{4}$. Residió una larga temporada en Tehuacán, donde en 1733 ejercía de juez de alcabalas, fue luego labrador y comerciante en Popotla-ocupaciones éstas que no lo alejaron del cultivo de las letras-, así como preceptor de niños en Orizaba y de gramática en el Seminario de Puebla, ciudad donde falleció, según Beristáin, en $1765^{5}$. Sin embargo, el bibliógrafo José Fernando Ramírez transcribe la dedicatoria de un manuscrito firmada y rubricada por Ruiz de León en Oaxaca, el 20 de agosto de 1773, lo que permitiría fechar su muerte casi una década más tarde ${ }^{6}$.

Homenaje a Ruiz de León, Tlaxcala, 1955 y Sobre dos gongorinos mexicanos: Ruiz de León y Reyna Zevallos, Gloria, Tehuacán, 1958.

${ }^{3}$ E. Cordero y Torres (op. cit., p. 608) transcribe el documento como sigue: "En la Ciudad de los Ángeles en veinte y nueve días del mes de abril de 1683 años: bautizó el S. doctor don Jerónimo de Luna, tesorero de esta Santa Iglesia Catedral, provisor y vicario general y gobernador de este obispado... habiéndole echado agua antes en su casa de dicho provisor el día doce de dicho mes de abril a Francisco Cayetano, hijo legítimo del capitán don José Ruiz Guevara y de doña María de León y Samora, fue su padrino el capitán regidor, don Francisco de Torija y lo firmó su merced el señor provisor don Guillermo de Luna”. Según el Diccionario Porrúa (loc. cit.) los progenitores se llamaron Joseph Ruiz Guerra y Juana de León Beltrán, lo que concuerda con el expediente incoado en Orizaba el año 1740 a favor de José Ruiz de León, Presbítero Cura de Coxcatlán y, sin duda, hermano del poeta, donde figuran además sus abuelos paternos, el capitán Cristóbal Ruiz y doña María Guerra, y los maternos, el capitán Diego de León Beltrán y doña Antonia de Zamora; véase Guillermo S. FERnÁndeZ de RecAs, Aspirantes americanos a cargos del Santo Oficio: sus genealogías ascendientes, M. Porrúa, México, 1956, p. 212. Un documento fechado en Puebla el 14 de febrero de 1686 completa la genealogía: como hermanos del testador, el capitán D. Francisco de Morales Guerra, vecino y residente en Puebla, son nombrados "el capitán D. José Ruiz Guerra... el capitán D. Bernardo Ruiz Morales... y D. Cristóbal Ruiz Guerra” (GuIllermo S. FernánDEZ DE Recas, Mayorazgos de la Nueva España, UNAM, México, 1965, p. 104).

${ }^{4}$ Casó primero con Rafaela Navarro y, tras enviudar, con María Josefa de Lara y Herrera (Diccionario Porrúa, loc. cit.).

5 Beristáin, Diccionario universal..., s.v. "Ruiz de León (D. Francisco)".

6 "Adiciones a la Biblioteca de Beristáin", en José Fernando Ramírez, Obras históricas. T. 4: Bibliografía y biografía, ed. E. de la Torre Villar, UNAM, México, 2001, p. 224. Se trata del Manifiesto a la república literaria de los fundamentos que han obligado a la reforma del Arte corriente de Nebrija, reducido a Epitome por el P. Juan Luis de la Cerda... Preséntalo Don Francisco Ruiz de León, hijo de la 
De su producción literaria destaca la Hernandia, impresa en 1755 y dedicada a doña María Bárbara de Braganza como intercesora ante Fernando VI, su regio esposo ${ }^{7}$. Escribió, asimismo, una mariología, Mirra dulce para aliento de pecadores, "rarísimo poemita de 333 décimas, muy devotas y muy conceptuosas, de probable publicación póstuma”, en palabras de Menéndez Pelayo $^{8}$, y que fue hecho imprimir en Bogotá por don Pedro Fernández de Madrid ${ }^{9}$. En el Prólogo de la Mirra dulce don Pedro menciona entre otros manuscritos uno cuya idea era "colocar a Felipe V en la categoría de los héroes grandes, para lo que describe sus heroicas acciones, las compara y da superiores a las de otros monarcas y sólo iguales a los héroes sagrados, que está en doce cantos" ${ }^{\prime 10}$. Beristáin, por su parte, registra una Tebaida india-

Nueva España..., ofrecido al duque de Alba que "por su mano tuvo el honor de presentar el poema de la Hernandia a los señores reyes don Fernando VI y doña María Bárbara..."

7 Hernandia. Triumphos de la fe, y gloria de las armas españolas, Poema heroyco. Conquista de México, cabeza del Imperio Septentrional de la Nueva-España. Proezas de Hernán-Cortés, cathólicos blasones militares, y grandezas del Nuevo Mundo, Madrid, Imprenta de la Viuda de Manuel Fernández y del Supremo Consejo de la Inquisición, 1755 (edición facsímil en Hernandia: Triunfos de la Fe y Gloria de las Armas Españolas... Los ensayos cortesianos de Fredo Arias de la Canal y otros papeles de la conquista, Frente de Afirmación Hispanista, México, 1989). Una copia digital del ejemplar de la editio princeps depositado en la Biblioteca Bodleliana de Oxford (A.S.N. 014208872) está disponible en http:// books.google.com., y la transcripción con grafía modernizada en la Biblioteca virtual Cervantes (http:/ /www. cervantesvirtual.com). Tengo referencia de otra edición (Hernandia, Rocinante, México, 1985, con presentación de Juan López), así como del opúsculo Hernandia. (Argumento y selección), Gobierno del Estado de Puebla, Puebla, 2002.

${ }^{8}$ En Historia de la poesía hispanoamericana, t. 1, p. 81. El título completo es Mirra dulce para aliento de pecadores, recogida en los amargos lirios del Calvario. Consideraciones piadosas de los acerbos dolores de María Santísima Señora Nuestra al pie de la Cruz, para agradecerle sus beneficios, acompañarla en sus penas e impetrar su intercesión para una buena muerte. Recopiladas en tiernos afectos métricos para mayor facilidad a la memoria, por D. Francisco Ruiz de León a instancias de un devoto, D. Antonio Espinosa de los Monteros, Santafé de Bogotá, 1791.

${ }^{9}$ Cuenta el prologuista cómo yendo al puerto de Veracruz con rumbo a España, encontró en la Villa de Orizaba a su viejo amigo, entonces preceptor de niños, que le confió los manuscritos para hacerlos imprimir en la Corte, pero sus múltiples ocupaciones le impidieron cumplir el encargo: véase Incunables bogotanos siglo XVIII, t. 1, Biblioteca Luis Ángel Arango-Imprenta del Banco de la República, Bogotá, 1959, consultado en http:// www.lablaa. org/blaavirtual/indice.htm.

${ }^{10}$ En Incunables bogotanos siglo XVIII, citado supra. Entre esos manuscritos probablemente estaría El pecador arrepentido: acto de contricción que compuso 
$n a$, en cuatro cantos, sobre la vida de los carmelitas descalzos en el Desierto de los Leones, así como de dos tomos manuscritos de "Poesías varias", algunas de las cuales se habrían publicado de manera anónima11.

Además de la poesía castellana, Ruiz de León cultivó la prosa, según la addenda bibliográfica de José Fernando Ramírez donde se mencionan tres obras sobre cuestiones gramaticales y otra de física experimental ${ }^{12}$. En el título de la principal -una corrección y enmienda del libro quinto de la Gramática de Nebrija- el autor aparece como humanarum sacrarum litterarum Professoris, lo que relacionaría estos tratados eruditos con su labor docente en el Seminario de Puebla ${ }^{13}$.

La larga vida de Ruiz de León transcurrió en tiempos del último Habsburgo y los primeros Borbones, un período de tránsito entre dos modelos de administración colonial que terminará desencadenando la aguda crisis donde, al calor de la Ilustración, germina la conciencia criolla hasta desembocar en la independencia de la Nueva España en 1821. En esta coyuntura nuestro vate se revela como un fervoroso panegirista de los

don Francisco Ruiz de León hijo de la Nueva España, una copia del cual, realizada en 1801, aparece en el Catálogo de la Biblioteca Nacional de Colombia (Fondo Pineda 381).

11 Aparte de Beristáin (loc. cit.), véase Peña, "Poesía épica”, p. 274. Desde el siglo xıx la Tebaida se suele dar por perdida, pero en el catálogo de la Universidad de Pennsylvania (UPenn Ms. Codex 191. Ff. 110-147) aparece la siguiente referencia a un ejemplar manuscrito: Thebaida yndiana, en cuya selba, trasplantadas las flores de el mas antiguo Carmelo, han brotado nuebos Pimpollos de la Gracia, a beneficio de el mejor Jardinero de el Jordán, San Juan Baptista: su fundación, origen, y observancia, descubierta en el decierto, que los Religiosos Carmelitas descalzos de la Provincia de San Alberto tienen fundado en las montañas de Santa Fee de la Nueba España: manuscript, [17 -].

12 RAmírez (“Adiciones a la Biblioteca de Beristáin”, pp. 223-225) describe detalladamente dos de estas obras: un volumen en parte impreso, en parte manuscrito donde "revela ingenio y estudio profundo de la lengua latina" (p. 224) titulado Aelli Antonii Nebrisensis, de Institutione Grammaticae libri quinque, olim iussu serenissimi Philippi Tertii Hispaniarum Regis Catholici, nunc denuo ab innumeris quae irrepserant mendis, defectibus, et erroribus idiomatisque puritatem restituti: regulisque quae antea defecerant accuratissime locupletati laboris et studio D. Francisci Ruiz de Leon humanitarum sacrarum litterarum Professoris; en cuanto al segundo, se trata del anteriormente citado Manifiesto a la república literaria de los fundamentos que han obligado a la reforma del Arte corriente de Nebrija...

13 Sobre la relevancia de los comentarios gramaticales en la instrucción de novicios y seglares, y su proyección editorial, véase IGNACio OsoRIo Romero, Floresta de gramática, poética y retórica en Nueva España (1521-1767), UNAM, México, 1980, pp. 103 ss. 
sucesivos detentadores de la Corona hispana: primero de Felipe $\mathrm{V}$, a quien cantó en una epopeya perdida, luego de Fernando VI, el destinatario de la Hernandia ${ }^{14}$, y finalmente de Carlos III, en cuyo homenaje por la entronización participó siendo casi octogenario $^{15}$. Esta devoción monárquica no sólo resulta coherente con su extracción social -su familia pertenecía a los niveles intermedios de la oligarquía administrativa, un grupo con intereses enfrentados a los criollos ${ }^{16}$-, sino que denota el deseo de hacer carrera literaria en la Villa y Corte, granjeándose el favor real y con el mecenazgo del duque de Alba ${ }^{17}$.

14 Parece que también compuso un elogio de la reina, según esta referencia del catálogo de la Biblioteca Nacional de México: Tristes ayes de la Águila Mexicana, reales exequias de la sereníssima señora da. María Magdalena Bárbara de Portugal, Cathólica Reyna de España, y Augusta Emperatriz de las Indias, celebradas en el templo Metropolitano de la Imperial Ciudad de México, los días 18 y 19 de mayo del año de 1759. Dadas a luz por los señores comisarios Lic. D. Joseph Rodríguez del Toro, Caballero de la Orden de Calatrava, y Lic. D. Domingo Trespalacios, Caballero del Orden de Santiago... Con licencia en la Imprenta de la Biblioteca Mexicana, año de 1760. Escrito por Francisco Ganancia, Cayetano Antonio de Torres, Agustín María de Castro y Navarro, Juan José de Eguiara y Eguren, Diego María Pimentel Sotomayor y Ossorio, Francisco Ruiz de León... (incluye Breve elogio, y descripción del real túmulo, en que se insinúan las principales partes, y ornatos de su arquitectura, imitando la idea, y metro de don Francisco Bances Candamo en su célebre descripción del río Tajo).

15 Según Peña ("Luces dieciochescas...”, p. 124), Ruiz de León fue el compilador del volumen conmemorativo titulado Amorosa contienda de Francia, Italia y España sobre la augusta persona de Carlos III, exaltado al trono español, México, 1761.

${ }^{16}$ Casi todos los varones de la familia fueron capitanes (véase supra, n. 3). Su padre, el capitán Joseph Ruiz Guerra, español peninsular, asiste en calidad de Alcalde ordinario a la firma de capítulos anexos a las Reales ordenanzas del gremio de loceros de Puebla, en un acta notarial fechada "en la ciudad de los Ángeles a dies y ocho días del mes de junio de mil seiscientos y ochenta y dos" (EnRiQue A. Cervantes, Loza blanca y azulejo de Puebla, México, 1939, t. 1, p. 30). Por otra parte, su padrino don Francisco de Torija debe de identificarse con un homónimo Regidor del Cabildo a finales del siglo Xvir. Capitán Regidor fue también Martín de Torija, hijo de Francisco de Torija y casado con la tía materna de nuestro poeta, doña Josefa de León Beltrán: cf. G. S. González de Recas, Aspirantes mexicanos..., p. 129.

17 Entre otras muchas dignidades, don Fernando de Beaumont, Silva y Álvarez de Toledo fue director de la Real Academia Española Matritense entre 1754 y 1776 . En los preliminares de la Hernandia, tras el soneto a doña Bárbara de Braganza, el poeta dedica otros dos al duque de Alba, significando su papel mediador en los tercetos de la última composición: "Parhelio, que al Rey Sol nos representa / siempre la Reyna fue Nuestra Señora, / y en la Reyna mirar mi Hernandia intenta // las luces, que el Rey Sol en sí 
Por lo demás, quizá el prestigio ganado con la Hernandia le permitiese radicarse en su ciudad natal, la Puebla de los Ángeles, de la que estuvo ausente largas temporadas, en su juventud por razones de estudio y más tarde desempeñando oficios diversos en entornos rurales. Sin duda, para un hombre cultivado y con ambiciones literarias resultaría más estimulante la llamada "Angelópolis", que constituyó un activo foco cultural bajo el poderoso influjo de la Compañía de Jesús, desde mediados del Xvir hasta la expulsión de la Orden en 1767. Cabe destacar que a inicios del siglo xvi aquí vivió uno de los primeros cantores de Hernán Cortés, Antonio de Saavedra y Guzmán, y poblano fue Gaspar Pérez de Villagrá, autor de una Historia de la Nueva México (1610) en verso suelto. A lo largo de la siguiente centuria crece el número de novohispanos que componen y editan en Puebla sobre todo hagiografías y poemas mariológicos de inspiración culterana, caso del ilustre polígrafo Carlos de Sigüenza y Góngora ${ }^{18}$. Y, en fin, "los últimos gongorinos de Nueva España" son dos poblanos, nuestro Ruiz de León y su coetáneo Miguel de Reyna Zevallos, autor de La elocuencia del silencio, poema heroico a san Juan Nepomuceno ${ }^{19}$.

\section{La HERNANDIA EN EL Giclo CORTESIANO}

El asiduo cultivo de la épica entre los literatos angelopolitanos demuestra la vigencia de la preceptiva literaria que desde el Renacimiento identificaba la epopeya con la poesía elevada y solemne. En sus dos vertientes, religiosa y profana, fue uno de los géneros más populares de los siglos áureos, algunas obras conocieron varias ediciones y llegaron, incluso, a ser traducidas a otras lenguas ${ }^{20}$. Así, los títulos impresos en la capital de la Villa y Corte testimonian el absoluto dominio de la poesía heroica durante

athesora: / ¿Luego una Alva a dos Soles me presenta? / Sí: que es tal Alva a dos soles Aurora" (hoja sin numerar).

18 Al respecto, José Toribio Medina, La imprenta en Puebla de los Ángeles 1640-1821, UNAM, México, 1991 (original, Santiago de Chile, 1908). Sigüenza y Góngora se preparó en el Colegio del Espíritu Santo de Puebla (ca. 1661-1667) para ingresar en la Compañía de Jesús.

19 Según Menéndez Pelayo, op. cit., pp. 79-80.

20 Sobre el tema, aparte de los trabajos de Pierce y Piñero citados en la nota 1, véase Giovanni Caravaggi, Studi sull'epica hispánica del Rinascimiento, Università di Pisa, Pisa, 1974. El Catálogo de Pierce (op. cit., pp. 329 ss.) recoge más de doscientos poemas épicos entre 1550 y 1600, que abarcan desde asuntos mitológicos e históricos a vidas de santos. 
el xvi y la historiografía de Indias en el siglo siguiente ${ }^{21}$. Al éxito de la epopeya contribuyó, sin duda, una coyuntura histórica singularizada por las campañas de Carlos $\mathrm{V}$ contra moriscos y turcos, y, en especial, por la Conquista de América, empresas donde se cimienta la ideología de un Imperio cristiano.

La conquista de la Nueva España, en concreto, originó una abundante literatura no sólo en forma de tratados, crónicas, cartas y memoriales, sino también de poemas narrativos ${ }^{22}$. Para empezar, la figura de Cortés, la descripción del país o la fundación de la Ciudad de México fueron evocados en composiciones variadas, entre las cuales descuellan los cantos XI-XV de Carlo famoso (1566) de Luis de Zapata, así como las semblanzas de Diego Velázquez y Francisco de Garay de las Elegías de varones ilustres de Indias (1589) escritas por Juan de Castellanos. A principios del XVII Bernardo Balbuena realiza en Grandeza mexicana (1604) una descripción minuciosa y entusiasta de la Ciudad de México como la "Nueva Arcadia”. Finalmente, Arias de Villalobos da muestras de un barroquismo exuberante al pintar las grandezas de Tenochtitlán, la cabeza del imperio de Moctezuma, en El canto intitulado Mercurio (1623).

En cuanto a la épica cortesiana propiamente dicha, destaca Francisco Terrazas, de cuyo inconcluso Nuevo Mundo y conquista se han conservado veintiún pasajes de transmisión indirecta ${ }^{23}$. Le sigue un discípulo de Ercilla, el noble Gabriel Lobo Lasso de la Vega, autor de Cortés valeroso y Mexicana ${ }^{24}$, y el ya mencio-

21 Al respecto, Yolanda Clemente SAn Román, "La literatura hispanoamericana en las prensas madrileñas de 1566 a 1625”, ALH, 22 (1993), pp. 51 ss.

22 Además de Wiston A. Reynolds, Hernán Cortés en la literatura del Siglo de Oro, Centro Iberoamericano de Cooperación-Editora Nacional, Madrid, 1978, véanse: para la historiografía, "Galería de cronistas", en JuAn Miralles, Hernán Cortés: inventor de México, ABC, Madrid, 2004, t. 2, pp. 546-580; para la épica, J.L. Martínez, "Poemas épicos y narrativos de la Conquista y cortesianos", en Hernán Cortés, UNAM-F.C.E., México, 1990, pp. 865-889; M. PEÑA, "La poesía épica en la Nueva España (s. Xvi)", en Historia de la literatura mexicana. T. 1: Las literaturas amerindias de México y la literatura en español del siglo XVI, coords. B. Garza Cuarón y G. Baudot, Siglo XXI, México, 1996, pp. 450-460; E.B. DAvis, "La épica novohispana y la ideología imperial”, en Historia de la literatura mexicana. T. 2: La cultura letrada de la Nueva España en el siglo XVII, coords. B. Garza Cuarón y R. Chang-Rodríguez, Siglo XXI, México, 2002, pp. 129-152.

${ }_{23}$ Aparecen intercalados en la Sumaria relación de las cosas de la Nueva España con noticia individual de los descendientes legítimos de los conquistadores y primeros pobladores españoles escrita por Baltasar Dorantes y Carranza hacia 1604 (edición con prólogo de E. de la Torre, Porrúa, México, 1987).

${ }^{24}$ De Cortés valeroso se imprimió por primera vez en 1588 con 12 cantos en octavas. La segunda edición, de 1594, enmendada y añadida con 25 cantos tomó el título de Mexicana. 
nado Saavedra y Guzmán con El peregrino indiano clausurando el siglo. En la primera mitad del xviI se fecha el manuscrito de Las Cortesiadas, cuyas 533 octavas de extremado culteranismo se atribuyen al jesuita Juan Cortés Osorio ${ }^{25}$. La crisis de la España de los Habsburgo arrastró consigo al género épico - el discurso mitificador por excelencia de la ideología imperial-, esfumándose el conquistador extremeño casi un siglo de la escena épica hasta renacer en los versos de Ruiz de León.

Se ha señalado que esta recuperación en la Hernandia de la figura de Cortés como un héroe positivo casa con el programa reformista de los primeros Borbones, concretamente, de Fernando $\mathrm{VI}^{26}$. Ahondando en esta perspectiva, no parece casual que el resurgimiento del género a mitad del siglo XviII se plasme en dos obras donde se actualizan y recuperan la Reconquista de España y la Conquista de América: el Pelayo de Alonso de Solís en 1754 y, un año después, de la Hernandia. Por lo tanto, en el horizonte de un nuevo concepto de "nación", acorde con la reforma político-institucional borbónica, cobraría sentido el revisionismo histórico de ambos poemas, que formulan este ideario en diálogo con la tradición ${ }^{27}$. Así pues, debajo de las urdimbres culteranas de la Hernandia destellarían, todavía en estado embrionario, algunos postulados político-ideológicos regeneracionistas, por lo que, paradójicamente, el "anacronismo" regalista de su autor podría interpretarse como signo de una "modernidad" sui géneris y condenada al fracaso ${ }^{28}$.

25 García Icazbalceta menciona otra Cortesiada escrita por el también jesuita Agustín Pablo Casado. Sobre ambos poemas, véase J. L. Martínez, Hernán Cortés, pp. 880-881.

${ }^{26}$ Cf. Maurizio Fabbri, "La Hernandia de Ruiz de León (1755) en la época del siglo xvin”, en La época de Fernando VI. Ponencias leídas en el Coloquio conmemorativo de los 25 años de la fundación de la Cátedra Feijoo, Instituto Feijoo de Estudios del Siglo XVIII, Oviedo, 1981, pp. 367-381. En la misma línea, Javier Yagüe Bosch, "La conquête du Mexique dans la littérature épique espagnole au XVIII siècle”, en L'épique: Fins et confins, ed. P. Frantz, PUF, Paris, 2000, pp. 254 ss.

27 Ruth A. Hill, "Conquista y modernidad, 1700-1766: un enfoque transatlántico”, en Fénix de España. Modernidad y cultura propia en la España del siglo XVIII (1737-1766), ed. P. Fernández Albadalejo, Marcial Pons, Madrid, 2006, pp. 65 ss.

28 Dice M. Peña (“Poesía épica”, p. 275): “el anacronismo principal del poema de Ruiz de León es su sentimiento monárquico adulador e hiperbólico, en un momento en el que el fervor nacionalista se encontraba en las plumas de los jesuitas expulsados". 
El valor paradigmático de Cortés en el discurso ilustrado sobre las relaciones entre la metrópoli y los territorios americanos explicaría que Las naves de Cortés destruidas fuese el tópico elegido en 1777 por la Real Academia para un certamen literario al que concurrieron, entre otros, Nicolás Fernández de Moratín y el ganador, José María Vaca de Guzmán ${ }^{29}$. Prueba de la actualidad del tema en el último tercio del siglo XVIII y el primer Romanticismo son, por una parte, México conquistado, poema heroyco (1798) de Juan de Escoiquiz y, por otra, La conquista de Mégico (1820) del ilustrado Pedro Montegón y Paret. Clausura el ciclo la inconclusa Conquista de Méjico de José García Gutiérrez (ca. 1855), de la que se conocen 39 octavas del canto primero y cuyas concomitancias con algún pasaje de la Hernandia podrían obedecer, sin más, a los cánones de la épica culta ${ }^{30}$.

\section{LA RECEPCIÓN CRÍTICA}

La feracidad poética de la materia cortesiana, equiparable a los ciclos sobre las conquistas de Perú y Chile, no lleva aparejado, sin embargo, el juicio favorable de la crítica, empezando por Manuel José Quintana, quien cierra la introducción a su "Musa épica" comentando a propósito de la Nápoles recuperada por el rey don Alonso del Príncipe de Esquilache ${ }^{31}$ :

No puede pues esta obra tener otra suerte que la que han tenido las Navas de Tolosa y los otros dos poemas de Cristóbal de Mesa; el Pelayo, de Alfonso López, dicho el Pinciano; la Mejicana, de Gabriel Laso; la Numantina, de Francisco de Mosquera; el Macabeo, de Silveira; el Alfonso y Nuevomundo, de Botello; la Hernandia, de Ruiz

${ }^{29} \mathrm{Al}$ respecto véanse: MaUrizio FABbri, "Las naves de Cortés destruidas en la épica española del siglo xviı”, RLit, 42 (1980), núm. 84, 53-74; CiARA O' Hagan, "Rewriting Spanish epic poetry in the Enlightenment period: Two competing interpretations of Las naves de Cortés destruidas", BSS, 86 (2009), 83-103.

30 Véase Luis Felipe Díaz Larios, "Anacronismo y desenfoque en la épica romántica (en torno a un texto inédito de García Gutiérrez)", en Romanticismo 2. Il linguaggio romantico. Atti del III Congresso sul Romanticismo Spagnolo e Ispanoamericano, Università di Genova, Genova, 1984, p. 62 y nota 27.

31 El poema heroico de don Francisco de Borja y de Aragón se publicó en Amberes (1651 y 1658). La cita procede de las Obras completas de MANUEL José Quintana, pról. de Ángel Ferrer del Río, BAE, 19, M. Rivadeneyra, Madrid, 1852, p. 173. A la historia crítica del género dedica PIERCE el primer capítulo de su ya citada obra, sobre Quintana versan las pp. 135 ss. 
de León. Todos ellos y los demás de su laya pueden figurar en buen hora entre los artículos de una bibliografía, mas no entre los monumentos del arte: pocos son los que no conozcan sus títulos, pero apenas hay quien los lea, y menos aún quien los estime. Queden pues en el descanso en que yacen, y no nos empeñemos en levantarlos de allí, y darles por cualquiera título algún interés en la atención de los lectores. Nuestros esfuerzos serían en balde; porque por su propio peso volverían irremediablemente a caer en el mar de olvido donde su nulidad los tiene anegados.

En el mismo sentido apunta Menéndez Pelayo a propósito del ciclo cortesiano ${ }^{32}$ :

No hay duda que Hernán Cortés ha sido, en general, poco afortunado con sus cantores... Un sólo episodio, como el de las naves dadas al través, pudo inspirar a Vaca de Guzmán algunas octavas robustas, patrióticas y valientes, y a Moratín el padre una sarta de descripciones brillantes que en tono y estilo y pompa de color salen mucho del pobre marco de la poesía del siglo XVIII, y más bien parece del tiempo de Lope o de Valbuena. Pero fuera de esto y del poema no acabado de García Gutiérrez, que más que realidad fue una promesa, los demás disputan entre sí la palma de la infelicidad, y quizá no es Saavedra de Guzmán, sino D. Juan de Escóiquiz, el que la merece de todo derecho por su intolerable México conquistada. Mas que los dos juntos vale Gabriel Lobo y Lasso de la Vega, que siquiera tenía condiciones de versificador, las cuales más bien sobraban que faltaban al ingenioso y gongorino poeta mexicano D. Francisco Ruiz de León, autor de la Hernandia. De todos modos, ninguno de ellos nos compensa la pérdida del poema de Terrazas, que vivió en mejor época literaria, y sintió mejor la poesía del argumento.

El erudito español concuerda, en lo fundamental, con el juicio previo de don Joaquín García Icazbalceta, quien tras comparar el "desmayado prosaísmo" de Saavedra con el "estilo embrollado y gongorino" de Ruiz de León, concluye:

Hay trozos de la Hernandia verdaderamente ininteligibles, y hasta dudo que el autor mismo pudiera dar razón de lo que quiso decir, pero en medio de esta insufrible hojarasca, y a pesar de algunos

${ }^{32}$ Historia de la poesía hispanoamericana, t. 1, pp. 38-39. 
versos duros o mal medidos, muestra Ruiz de León verdaderas dotes de poeta ${ }^{33}$.

Beristáin, por su parte, aun considerando la Hernandia un "poema heroico de escaso mérito", significa cómo su descrédito obedecía, fundamentalmente, a la transformación del gusto literario ${ }^{34}$ :

Y si en la Jerusalén del Tasso, en el Paraíso de Milton, en la Luisiada de Camoens, en la Araucana de Ercilla y en la Henriada del libertino, pero buen poeta Voltaire, se han hallado grandes defectos, ¿Cómo podría gloriarse la Hernandia de un poeta americano de haber llenado todas las leyes de la epopeya y todo el gusto de los literatos? El que reinaba entre nosotros por el año 50 del siglo XVIII no era ciertamente el mejor; y a esto y no al ingenio y erudición del autor deben atribuirse los pecados que haya cometido contra el arte, su estilo y pensamiento metafísicos. Y si cuando volvió a renacer en el parnaso español el buen gusto en la poesía se ha cebado con nuestra Hernandia la crítica de algunos buenos poetas, también mereció a los de su tiempo algunos elogios singulares.

Así, en los habituales preliminares de la Hernandia el Censor, don Joaquín de Buedo y Girón ${ }^{35}$, resalta la calidad de su fuente

33 Tomo la cita de J.L. Martínez, op. cit., pp. 878 ss. También se pronuncian negativamente Ticknor, Cejador o Morales Padrón: cf. M. FABBRI, "La Hernandia...", pp. 370-371.

34 Además del Diccionario universal, s.v. "Ruiz de León (D. Francisco)", véase el extracto de la Biblioteca hispanoamericana septentrional en M. PEÑA, "Luces dieciochescas...", p. 122. Su juicio encuentra eco en TAdeO OrTIZ Y Ayala, México considerado como nación independiente y libre, Imprenta de Carlos Lawalle Sobrino, Burdeos, 1832, pp. 219-220. [Digitalizado en http:/books. google.com].

35 En Sor Juana a través de los siglos (El Colegio de México-UNAM, México, 2007, t. 1, p. 597, nota 5) don Antonio Alatorre (q.e.p.d.) considera demostrado que la Hernandia es obra del jesuita Juan de Buedo y Girón, hermano del Censor, siguiendo al P. Eugenio URIARTE (Catálogo razonado de obras anónimas y seudónimas de autores de la Compañía de Jesús pertenecientes a la antigua asistencia española..., Sucesores de Rivadeneyra, Madrid, 1906, t. 3, pp. 220-221). [Agradezco la noticia y ambas referencias a uno de los lectores anónimos de este ensayo]. Uriarte, a su vez, pese a "la constancia y seguridad absoluta con que los críticos y literatos, así españoles como extranjeros, convienen en atribuir este Poema a Ruiz de León”, acepta el testimonio del P. Ramón Diosdado Caballero (mss., núm. 462, Bibliothecae Scriptorum Societatis Jesu Supplementa, 1814-1816): que Buedo tomó el nombre de Ruiz de León para evitar la censura de sus superiores por su afición a las “musas 
documental, la Historia de la conquista de México, población y progresos de la América septentrional, conocida con el nombre de Nueva España (1685) de Antonio de Solís y Rivadeneyra, aparecida en 1684 y cuya séptima edición en el Xvin prueba la alta estima de que gozó entre los escritores de la centuria ${ }^{36}$. De hecho, el aprobante y panegirista de la Hernandia, don José Joaquín Benegasi

prophanas" y que él "oyó siempre en España que Juan [de Buedo y Girón] fue el autor de este Poema", rumor confirmado en una carta de enero de 1804 por Julián Buedo, sobrino de Juan y condiscípulo suyo. Además de los diez impresos recogidos por Francisco Aguilar Piñal, Biblioteca de autores españoles del siglo XVIII, CSIC, Madrid, 1981, t. 1, pp. 732-733), Juan de Buedo y Girón (Cuenca, 1702- Forli, 1773) firma el manuscrito La Compañia de Jesús Triunfante: vidas heroicas de los santos canonizados en los dos primeros siglos de ella, reducidas al metro castellano... Año 1759 (cf. Boletín bibliográfico español y estranjero, Imprenta de Hidalgo, Madrid, 1844, t. 4, p. 381). Sin embargo, aunque en la relación de Aguilar Piñal aparecen una obra anónima (núm. 5188: Comedia nueva, intitulada: la rosa de Alexandría, Santa Eugenia. De un ingenio de esta Corte [Madrid, 1735]) y otras dos con el seudónimo de Joaquín de Anaya y Aragonés (Vencer y ser vencidos: Anteros y Cupido, zarzuela en dos jornadas [Madrid, 1735] y Rasgo métrico con que se delinean las fiestas que la M. I. Ciudad de Alicante hizo... celebrando la felicidad de la exaltación al trono de Fernando VI... [1746], números 5187 y 5195, respectivamente), no hay mención alguna a la Hernandia ni a Ruiz de León. En ausencia de otros documentos que convaliden la atribución del P. Caballero, dilucidar este problema requeriría de un exhaustivo análisis filológico-comparativo, lo cual desborda los objetivos del presente trabajo.

${ }^{36}$ Véanse el Romance heroyco en elogio de don Francisco Ruiz de León, autor de la Hernandia... escrito por Juan de Buedo Girón ("Del Pindo Indiano Americana Musa, / porque a la España se creyó deudora, / sólo en Solís de una memoria eterna / le paga en verso, lo que le dio en prosa") y la Censura donde Joaquín de Buedo y Girón afirma: "La heroycidad de la Conquista de México subió a la cumbre del valor, y de la honra..., en la singularísima persona de Hernán-Cortés. Logró también el verse colocada en la mayor elevación de la elocuencia española, cuando Don Antonio de Solís la dexó eternizada en las esmeradas, puras, castizas voces, con que dio leyes a los Historiadores Españoles su lucida pluma" (textos en hoja preliminar sin numerar). No obstante, Solís tuvo detractores tan conspicuos como el también jesuita Francisco Javier Clavijero quien en la "Noticia de los escritores de la historia antigua de Méjico ss. Xvi-Xviı" (1780) dice: "Su lenguaje es puro, y elegante, pero el estilo afectado, las sentencias alambicadas, y las arengas sacadas de su imaginación. Como que no buscaba lo verdadero, sino lo bello, contradice muchas veces a los autores más dignos de fe, y aun al mismo Cortés, cuyo panegírico escribe" (cito por Historia antigua de Mégico sacada de los mejores historiadores españoles, y de manuscritos, y de las pinturas antiguas de los indios, traducida del italiano por José Joaquín de Mora, R. Ackermann, London, 1826, t. 1, p. xxv, digitalizada en http://books.google.com). 
y Luján, concluye el soneto en Aplauso de la obra diciendo 37 : "El Insigne Solís tu Norte ha sido, / y en mucho (que no es poco) le imitaste; / ¡Oh!, iquánto en esto sólo has conseguido! // Ya es ocioso decir te remontaste: / porque no siendo así, ¿quién ha podido / seguir al que seguiste, y alcanzaste?". Al respecto, se pronuncia, de nuevo, don Marcelino:

Por lo demás, el autor se limita a poner en endecasílabos, de estilo afectado y pomposo, La Conquista de México, de Solís, resultando mucho menos poeta en versos que el historiador en prosa, sin que por otra parte se trasluzca que hubiera pisado siquiera la tierra que describe: tales son de arbitrarias y confusas sus descripciones ${ }^{38}$.

Llegados a este punto, cabe reivindicar para la Hernandia la exhortación de Piñero a "estudiar y valorar el poema épico desde la misma época que lo produjo y lo leyó”, perspectiva crítica en la que insiste Margarita Peña ${ }^{39}$ :

Finalmente se debe señalar que la épica del siglo XviII, tan importante dentro de su contexto concreto como la épica de los siglos XVI y XVII, se encuentra enterrada en archivos y bibliotecas. Ni la Hernandia de Ruiz de León, ni México conquistada de Escoiquiz, ni otros muchos poemas heroicos, han merecido la atención de especialistas. Las ediciones críticas, o simplemente comentadas, o los estudios que se aproximaran al texto desde varios ángulos, harían posible que todo el panorama del género épico de la América colonial se reuniese en el futuro.

Mientras este desiderátum se plasma en una edición crítica de la Hernandia como las recientemente dedicadas a otras epopeyas cortesianas ${ }^{40}$, aquí se aborda un asunto concreto: la impor-

37 Tercetos en hoja preliminar sin numeración.

38 Historia de la poesía hispanoamericana, t. 1, p. 81.

39 Véanse Piñero, art. cit., p. 162 y PeÑA, "Poesía épica”, p. 279. Con sendas invitaciones a analizar nuestro poema en su siglo concluyen FABBRI, "La Hernandia...", p. 381 y Andrés Morales, "Visión de Hernán Cortés como personaje histórico y protagonista literario de la Hernandia, del novohispano Francisco Ruiz de León”, en Rebeldes y aventureros: del Viejo al Nuevo Mundo, eds. H. R. Cortés, E. Godoy y M. Insúa, Iberoamericana, Madrid, 2008, p. 193.

40 Véanse Gabriel Lobo Lasso de la Vega, De Cortés valeroso y Mexica$n a$, est. prelim., transcr. y notas de Nidia Pullés-Linares, Iberoamericana, Madrid, 2005; Antonio de SaAvedra y Guzmán, El peregrino indiano, ed., introd. y notas de María José Rodilla León, Iberoamericana-Universidad Autónoma Metropolitana, Madrid-México, 2008. 
tante presencia de la cultura clásica en el poema, hecho que, en principio, obedecería tanto a la preceptiva del género como al barroquismo crepuscular de su autor.

\section{LA HERNANDIA Y LA TRADICIÓN CLÁSICA ${ }^{41}$}

Más allá de su variedad temática, la épica culta constituye un género rigurosamente codificado, cuyas pautas y lugares comunes emanan, en lo fundamental, de la definición aristotélica de la poesía como mímesis, esto es, "reproducción imitativa". En el ámbito hispano además de los prototipos grecolatinos -Homero, pero sobre todo Virgilio y Lucano-, fueron determinantes las actualizaciones de argumento y canon nacidas en Italia ${ }^{42}$. La Hernandia, por su parte, responde fielmente a las formalidades del género, desde el metro utilizado -la estrofa de endecasílabos conocida como octava rima o real, el "verso heroico" por antonomasia-, hasta la división en doce cantos siguiendo el ejemplo de la Eneida, o la denominación de Poema heroyco del subtítulo ${ }^{43}$.

A propósito de la epopeya renacentista señalaba Highet que "la influencia clásica lo penetra todo" 44 , e igual valdría para la Hernandia a la vista de las menciones de la historia, las artes y la mitología presentes en buena parte de sus estrofas. Ahora bien, una vez detectados tales tópicos en la epidermis del poema, cabría contextualizarlos abordando su función, ya que, además de "anacronismos" responsables en gran medida de la "insufrible hojarasca" que estorba a los lectores ${ }^{45}$, resultan consustan-

${ }^{41}$ Sobre los tópicos virgilianos versó mi ponencia inédita "Estragos canto del cruento Marte: la Hernadia en la tradición épica”, presentada en el XVII Coloquio Internacional de filología griega (UNED, Madrid, 18 de marzo de 2007). En las citas literales adecuo la grafía de la edición príncipe (véase supra nota 7), acentuada de acuerdo con la normativa actual.

${ }^{42}$ Cf. Poética, 1-3, 1447a-1448b; 23-24, 1459a-1460b (concepto de mímesis y caracterización de la epopeya, respectivamente). Además de los precitados estudios de Pierce, Piñero y Caravaggi, véase José Lara Garrido, Los mejores plectros: teoría y práctica de la épica culta en el Siglo de Oro, Analecta Malacitana, Málaga, 1999.

${ }^{43}$ Cada uno de los doce cantos de Hernandia va precedido de su argumento en prosa y de una octava introductoria, seguidos de un número variable de estrofas, que oscila entre las 102 octavas del Canto VII y las 149 del Canto XII, resultando un total de 1477 estrofas y 11816 versos.

${ }^{44}$ En La tradición clásica, F.C.E., México, 1996, t. 1, p. 233.

${ }^{45}$ Las expresiones entre comillas son de PeÑa ("Poesía épica", p. 275) y GARCÍA de IzCAZBALCETA (apudJ. L. Martínez, op. cit., pp. 878-879), respectivamente. 
ciales con la arquitectura y el significado de la Hernandia, como se intentará demostrar en las páginas siguientes.

\section{LA POÉTICA}

Uno de los hitos de la épica culta consiste en anteponer a la narración propiamente dicha un "prólogo" o "proposición" donde, según los preceptos de la retórica, se presenta y justifica el argumento ${ }^{46}$. A imitación de los modelos consagrados, el poeta suele invocar aquí el auxilio de instancias sobrehumanas y, a veces, dedica la obra a un poderoso. Pese a su convencionalismo, el prólogo se configura como un metatexto especular donde el autor, a partir de la dialéctica entre inventio y mímesis que condiciona la escritura, no sólo demuestra su maestría emulando a sus predecesores, sino que, a la vez, toma posición respecto a ellos, de donde la frecuente enunciación en primera persona, pese a Aristóteles ${ }^{47}$. Los tratadistas, por otra parte, aconsejaban que esta sección fuese breve -siete hexámetros ocupa en la Eneida y ocho en la Farsalia-, pero en la épica barroca devino un escaparate para el lucimiento de arte y erudición y, así, el prólogo de la Hernandia ocupa las veintiún primeras estrofas del Canto I ${ }^{48}$. Ruiz de León comienza abordando el género y el tema de su canto, para luego declarar las motivaciones y dificultades de una empresa que ofrenda a Fernando VI y para la cual solicita el concurso divino. Dice la primera octava:
No canto endechas, que en la Arcadia umbrosa, al vasto son de la zampoña ruda, lamenta a la zagala desdeñosa tierno pastor, para que a verle acuda: delirios vanos de passión odiosa, que a la alma ciega, y a la lengua muda dexan, cuando explicados, o sentidos, roban el corazón por los oídos.

46 La nomenclatura deriva de Aristóteles (Retórica, III, 13-14, 1414 a-b), quien al tratar de las partes del discurso, distingue entre próthesis ("proposición”) y pistis (“argumentación”).

47 "El poeta mismo ha de hablar lo menos posible" (Poética 14, 1460a). Sobre la función del prólogo, véase CaRAVAGgi, op. cit., pp. 115 ss.

48 En la Filosofía antigua poética (1596) Alonso López el Pinciano prescribía que la proposición y la invocación cupiesen "en una hoja sola" (cf. CARAvaGGI, op. cit., p. 170, n. 2). Cinco octavas ocupan en la Araucana e igual número en la Mexicana de Lobo, mientras que el prólogo de la Jerusalén conquistada de Lope tiene ocho y el Peregrino indiano de Saavedra catorce. 
Si en la obertura de la Araucana -"No las damas, amor, no gentilezas / de caballeros canto enamorados"- Ercilla respondía al Orlando de Ariosto ("Le donne, i cavallier, l' arme, gli amori, / le cortesie, l'audaci imprese io canto"), el referente del autor de la Hernandia resulta ser Garcilaso, en concreto el prólogo de la Égloga III, del que toma el endecasílabo "al bajo son de mi zampoña ruda", un verso ya empleado por Terrazas ("si al bajo son de mis groseras cañas / no pudiera cumplir lo prometido") y de amplio eco en el Barroco ${ }^{49}$. En la segunda estrofa la negación de la bucólica se extiende del idilio a las estampas de la vida simple ${ }^{50}$ : "No los ocios de rústica montaña, / donde de albogues al compás grossero / guarda su sencillez, y su cabaña / de assechanzas, y lobos el cabrero: /...no de la abeja, laborioso esmero, / dan aliento a mi voz, pues hoy con arte, / estragos canto del sangriento Marte".

El último verso recuerda a "Entre las armas del sangriento Marte", la milicia desde donde Garcilaso entona su pastoral, una situación de partida inversa a la de Ruiz de León quien, viviendo en el campo, ha optado por la musa épica. Sin embargo, el referente último de ambos poetas resulta ser Virgilio: quizá la Égloga X en el caso del toledano ${ }^{51} \mathrm{y}$, sin duda, la Eneida para el de Puebla. En efecto, "Estragos canto del sangriento Marte", se corresponde con At nunc horrentia Martis, el final del prefacio apócrifo de la Eneid $a^{52}$ que daba paso a la celebérrima endíadis

49 Égloga, III, 40 ss.: "Aplica pues un rato los sentidos / pues de al bajo son de mi zampoña ruda, / indigna de llegar a tus oídos, / pues de ornamento y gracia va desnuda”. Góngora, en la dedicatoria del Polifemo al Conde de Niebla dice: "Éstas que me dictó, rimas sonoras, /...escucha, al son de la zampoña mía”. También Sigüenza y Góngora (Primavera indiana, LXXIX): "Tenue la voz, pequeña la armonía / al son cantaba de la zampoña ruda". Para otras imitaciones de este topos, véase Antonio Vilanova, Las fuentes del Polifemo, CSIC, Madrid, 1957, pp. 181-185.

50 Cera, cañas y albogues se aúnan en la zampoña, instrumento del "bárbaro ruido" de Polifemo en la Fábula de Góngora (estrofa XII). CALDERón, por su parte, parafrasea a Garcilaso evocando los tiempos primitivos (La estatua de Prometeo, Jornada I): "Venid, pues, venid trayendo / de vuestras zampoñas rudas, / de vuestros rudos albogues / las armonías confusas".

51 Compárense Virgilio, Égloga, X, vv. 44 ss. con Garcilaso, Égloga III, vv. 33 ss. Por lo demás, el bucolismo como evasión es un motivo recurrente ya en las Odas de Horacio.

${ }^{52}$ [Ille ego, qui quondam gracili modulatus avena / carmen, et egressus silvis vicina Coeli / ut quamvis avido parerent aeva colono, / gratum opus agricolis, at nunc horrentia Martis] // Arma virumque cano... En la biografía de Donato y los Comentarios de Servio estos versos se atribuyen a Virgilio, aunque desde 
arma virumque cano, un lugar casi obligado en la épica y que Ruiz de León parafrasea en el arranque de la estrofa tercera: "Las armas canto, y el varón glorioso, / que labrando a sus manos su oportuna / suerte, constante, diestro, generoso, / sobre los astros erigió su cuna...”. El famoso hemistiquio reaparece más adelante cuando, tras caracterizar al héroe (virum), se atiende a las hazañas bélicas (arma) y a los antagonistas: "Sangrientas guerras, canto de terribles / generosas cuchillas españolas /... arduos encuentros, cóleras horribles, /...entre españoles, y entre americanos" (I, 6).

Una vez delimitado, en negativo y positivo, el género literario, nuestro poeta fija su lugar en la tradición desmarcándose de los modelos, pasaje éste con reminiscencias de Camoens ${ }^{53}$. Interpela, primero, a Virgilio conminándole a enmudecer, ya que sus criaturas pertenecen a la ficción mitológica mientras que en la Hernandia alienta la verdad (I, 7): "Cesse ya del Mantuano la chymera, / que en la épica, con docta fantasía, / pintó; pues hoy admira verdadera, / serie mayor de intrépida ossadía" 54 . A la Farsalia de Lucano, prototipo de las epopeyas de tema histórico, se alude en la relación de personajes famosos y antiguas guerras menoscabados por el superior heroísmo de los españoles, una idea recurrente en el poema y con correlatos casi literales en la "cortesiada" de Lobo $(\mathrm{I}, 8)^{55}$ :

antiguo fueron tachados de apócrifos y eliminados. Figuraban, sin embargo, en muchas ediciones renacentistas de la Eneida, de ahí su recreación, por ejemplo, encabezando la Gatomaquia de Lope o el Ignacio de Cantabria: véanse, respectivamente, VicENTE Cristóbal, "De la Eneida a la Araucana", Cuadernos de Filología Clásica. Estudios Latinos, 9 (1995), p. 70; Modesto CALDERÓN, "La Eneida como modelo de la épica culta española de tema religioso: el Ignacio de Cantabria de Pedro de Oña", Cuadernos de Filología Clásica. Estudios Latinos, 17 (1999), p. 63, n. 14.

${ }^{53}$ Cf. Os Lusíadas I, 3: "Cessem do sábio Grego e do Troiano / as navegações grandes que fizeram; / cale-se de Alexandro e de Trajano / a fama das vitórias que tiveram; /...Cesse tudo o que a Musa antígua canta, / que outro valor mais alto se alevanta".

${ }^{54}$ En términos parecidos se expresaba siglos antes PÉREz de GuZMÁN (Loores de los claros varones de España, XLVII): "Vaya Virgilio cantando / su arma virumque cano / proceso inútil e vano / a Eneas magnificando... / la poca e pobre sustancia / con verbosidad ornando". Con todo, Ruiz de León dirá en otro lugar (X, 106): "En este empeño cruel, en este trance, / era justa, mantuano, la ternura / con que lloraste la perdida joya, / de tu encendida desolada Troya".

${ }^{55}$ Compárese con Mexicana, XV, 15: "Callen con este hecho los famosos / de Alejandro, Pompeyo, Julio y calle / aquél de los helvecios belicosos..."; XXIII, 10: "¿Qué Pompeyo, triunfando en edad tierna / del contrastado 


\begin{abstract}
Borren desde oy los Julios, y Scipiones, Alexandros, Pompeyos, y Annibales, de Roma, y de Numancia los blasones, de Carthago, y Farsalia los annales: que más heroycos célebres campeones obscurecen sus tymbres inmortales, cuanto va de vencer lo que es factible, a reducir al acto lo imposible.
\end{abstract}

Tan magna gesta justifica el embarazo del poeta, una forma de captatio benevolentiae que desarrolla hilvanando diversos motivos clásicos. Así, a la teoría sobre la poesía como manía o "furor divino" derivada de Platón, le sucede la imagen virgiliana de la inspiración manando de Hipocrene, la fuente del Helicón donde se reúne el cortejo apolíneo, en esta estrofa cuyo verso final recuerda a Góngora $(\mathrm{I}, 12)^{56}$ :

A tanto assunto, Numen más canoro, inflamado en los raptos de la mente, era debido, que con cuerdas de oro cantase assombros de su continente: de la docta Hypocrene al sacro coro precisaba su número cadente, y aun fuera corta lyra en esta parte el mismo Apolo, para el propio Marte.

En tal tesitura, como ya hiciese Homero y tras él toda una pléyade literaria, el autor de la Hernandia llama en su auxilio a las musas, concretamente a la patrona de la Historia (I, 17) ${ }^{57}$ : "Tú Piéride sagrada, heroyca Clío, / cuya voz es imán dulce del viento, / con tu furor inflama el labio mío, / haciendo menos

Hiarbas, hizo tanto? / ¿Qué Julio, qué Escipión de fama eterna, / qué Alejandro, que al mundo puso espanto? /...¿¿ cuál Aníbal, Pirro, Emilio, Antonio / dejó de su valor tal testimonio?".

56 Cf. Platón, Ión, 533d-534e; 536; Fedro, 244a-245c; Virgilio, Eneida, VII, 641; X, 163. Góngora en la dedicatoria "A Juan Rufo, de su Austriada" escribe: "Él de la espada del sangriento Marte, / vos de la lira del sagrado Apolo". Garcilaso se sirve del mismo contraste, "ser otro Marte en guerra, en corte Febo" (Égloga, II, 1190), recreando en honor del duque de Alba la expresión de Juan de Mena para el marqués de Santillana: "en corte grand Febo / en campo Aníbal".

57 Más adelante (II, 90) apela a la musa épica: "Aquí tu voz, tu Plectro aquí cadente / soberana Caliope, que gastado / está en heroycidades de la España, / elogiar sólo puede tanta hazaña”. 
bronco su concento: /...esté al influxo, con que tu aura inspira, / para héroe tanto, más capaz la lyra”.

En otro lugar, Ruiz de León, a quien "No de vil interés ciega codicia / mueve en la mano fatigado buelo; / la razón, la verdad, y la justicia, / le dan impulsos a escalar el cielo" (I, 15), se dirige a Fernando VI significándole: "España, tú, mi rey, hacen factible / copia, que fue impossible a mis bosquexos" (I, 67). No obstante, armonizar el amor a la patria con los preceptos del arte, cantando al campeón de esos guerreros españoles para los cuales "poco eran los Virgilios, los Homeros" (XII, 141), exige el concurso del príncipe de los poetas, como ilustran estos versos (I, 88): "Mano al retrato, que si suave inspira / Apolo el numen, no ha de andar escaso, / si al tiento tabla, si al concento lyra, / pulso, y voz van por cuenta del Parnaso /...debe aquél de tributo, dando pruebas, / canoro hacerlas en el metro nuevas" 58 .

Con todo, la ayuda divina no impide que, en ocasiones, las fuerzas flaqueen. Así, cuando Cortés zarpa desde Cuba rumbo a México entre las insidias y maledicencias de sus enemigos, el vate sabiendo que este primer escollo no es el mayor de los que aguardan al héroe, interrumpe la narración para preguntarle (I, 86):

Y ¿̇ómo ha de poder buelo grossero de pluma tan pequeña remontarse a región superior, donde altanero, del tonante el garzón llegó a cegarse?

Si a tus hechos no alcanza dulce Homero, ¿ella qué hará? ¿Dexarlo? No. Alentarse: si aquel no acierta, forma el sylogismo, pues para errar, cualquiera hará lo mismo.

Un mosaico de referencias grecolatinas con ropaje culterano se concita en esta octava en torno a la consabida mediocritas del autor frente la virtus del protagonista ${ }^{59}$. En efecto, los pri-

58 El mismo motivo en VII, 110 (“iOh, quién feliz del Helicón sagrado / mereciesse el raudal! Apolo pío, /...Cantaré con tu ayuda el elevado / héroe, pero aún con ella desconfío; / que si bien el aliento me concedes, / mas cantar a Cortés, tú sólo puedes") y en VIII, 102 ("Sube, sube, y eleva tus blasones / a que los cante, con melifluo acento, / sagrado Apolo, pues de tus acciones / él sólo puede ser cabal comento”).

${ }^{59}$ Sobre el particular insiste, entre otros lugares (I, 18; II, 90; VI, 44; VIII, 8, 9, 101, 111; IX, 78), en la última octava de la Hernandia, dirigida al Rey (XII, 149): "Aquí, si acaso hubieseis escuchado, / (¡qué favor!) Sacro Augus- 
meros cuatro versos recuerdan la Oda de Horacio (Carminum, II, 17, donde el poeta, convertido en cisne, se compara con Ícaro, el personaje mitológico aquí aludido), la cual recrea, a su vez, el pasaje del Fedro (246a -247d) sobre el vuelo del alma hasta las esferas supracelestes como alegoría de la inspiración y del impulso erótico, vetas ambas del "icarismo" explotadas por Góngora y Villamediana, entre otros ${ }^{60}$. No obstante, Ruiz de León habría podido beber en la más cercana fuente de la "Décima Musa", sor Juana Inés de la Cruz, quien había hecho de la ascensión y caída de Ícaro -y de Faetonte- no sólo el emblema de los precipicios de la vanidad, sino, en particular, de los límites de la humana palabra ${ }^{61}$. De hecho, la segunda parte de nuestra estrofa apunta de manera críptica a la cuestión adyacente de cómo hacer compatibles ingenium y ars, esto es, inspiración y oficio. Según la doctrina aristotélica, el arte (téchne) del poeta épico consistía en expresar lo "admirable" en términos de "verosimilitud", incluso en el caso de hechos falsos o no sucedidos, lo que implicaba anteponer "la imposibilidad verosímil, a la posibilidad increíble", esto es, el paralogismós o "falso silogismo"62. El filósofo, además, nombra a Homero maestro insuperable en este arte, de manera que aplaudir o rectificar su juicio, como aquí hace nuestro autor, devino una convención literaria ${ }^{63}$.

to, excelso Numa, / los broncos ecos del marfil templado, / mal pulsado del plectro, y de la pluma, / hace pausa el aliento fatigado / en este ensayo, porque lo es en suma, / mientras remonta vuelo más gigante, / cuando la lyra vuestras glorias cante".

${ }^{60}$ Así en la Soledad Segunda (vv. 141 ss.) que dice: "Audaz mi pensamiento / el cenit escaló, plumas vestido...”. De la ceguera de Ícaro -trasunto del poeta enamorado- arranca el soneto 29 de Villamediana: “;Oh volador dichoso que volaste / por la región del aire y la del fuego, / y en esfera de luz, quedando ciego, / alas, vida y volar sacrificaste!".

${ }^{61}$ En VI, 42-47, al pintar las bellezas de Amecameca, su región natal, Ruiz de León asemeja a esta "Heroyna rara" con el Fénix, Telesila, Nicóstrata, Clío, Cleobulina, Safo, Corina, Areta, Aspasia y Eustoquio. Para el tópico en sor JuAna, además de la alegorización neoplatónica del mito en Primero sueño (vv. 455 ss.; 781 ss.), véase esta copla: "No el asunto satisfago, / que pide Numen Divino, / pues no el término, termino, / en que náufrago, naufrago. // La audacia, que sin reparo, / tantos riesgos acumula, / si la luz émula emula, / vendrá a ser Ícaro, y caro" (Dedicación del Convento de San Bernardo, letra XXIV).

${ }^{62}$ Cf. Poética, 24, 1460a. Sobre este principio insiste Horacio (Epistola ad Pisones, vv. 305 ss.).

${ }^{63}$ Por ejemplo, Pérez de GuzMán (Loores de los Claros varones de Espa$\tilde{n} a$, XI: "¿Por qué [España] no fue dotada / de tan alto pregonero / como Gresçia de Omero / en la famosa Iliada?”; XIII: "Para que bien se igualasen 
Aunque en el subtítulo de la Hernandia los Triumphos de la fe, y gloria de las armas españolas preceden a las Proezas de Hernán Cortés, la figura del extremeño constituye la columna vertebral del poema, siguiendo el modelo sancionado por la Eneida frente al protagonista colectivo de epopeyas historicistas como la Farsalia o la Araucana. $\mathrm{Al}$ igual que Eneas, Cortés está llamado a cumplir una misión trascendental -en su caso, conquistar una Nueva España para el emperador cristiano-, frente a poderosos adversarios, arrostrando toda suerte de penalidades cuya superación constituye no sólo la piedra de toque del heroísmo, sino el fundamento de su ejemplaridad.

El Cortés de la Hernandia coincide, en lo esencial, con el héroe conquistador y evangelizador predominante en la tradición, si bien se acentúan sus rasgos de explorador y hábil diplomático en consonancia con la política pacificadora de Fernando VI, invocado como "excelso Numa", el piadoso sucesor de Rómulo en el trono de Roma (XII, 149). También mediante epítetos y símiles alusivos a personajes de la Antigüedad se resaltan las distintas facetas de la virtus del extremeño, procedimiento éste habitual en el discurso epidíctico desde finales del Medievo. Así, es asimilado al dios Marte en excelencia militar, a Alejandro y Escipión por sus conquistas, a Remo en cuanto cofundador de un imperio, mientras que su perspicacia sirve de espejo a Minerva, en fuerza viril se iguala a Hércules y supera a Agatocles y Timarco en audacia estratégica ${ }^{64}$. En este punto, cabe destacar, por una parte, que Julio César -el personaje más nombrado tanto en los encomios de la poesía prerrenacentista como en la literatura cortesiana ${ }^{65}$ - comparezca en una única ocasión,

\footnotetext{
/ debían ser los caballeros / de España, e los Omeros / de Greçia que los loase") y Lope DE VEGA (Jerusalén conquistada, VII, 3: "griego fue Homero, si mis versos viles / vence, yo a él en más gallardo Aquiles").

64 Véanse: II, 89 (católico Marte); VII, 29: (Marte castellano); VII, 96 (retrato de Marte); X, 57 (el extremeño Marte); X, 146 (heroico Marte); XI 27 (el humano Marte); XII, 98 (cristiano Marte); XII 137 (castellano Marte); X, 146 (Alejandro español); XI, 137 (Macedón segundo); IX, 107 (Escipión español); IX, 115 (nuevo Escipión); XII, 137 (Escipión heroico); VIII, 9; XII, 139 (Remo); II, 93 (Minerva); II, 34 (extremeño Alcides); VII, 13 (castellano Hércules Alceo). La alusión a los "de Etolia y Sicilia... /...caudillos atrevidos / que por vencer quemaron sus baxeles” (II, 9) está inspirada en Solís (Historia de la conquista de México, II, 13).

${ }_{65}$ Al respecto, véase Reynolds, op. cit., pp. 115-126: "Cortés y los héroes de la Antigüedad".
} 
significándose, además, su soberbia, de acuerdo con una valoración proveniente, en último término, de Lucano ${ }^{66}$. Por otra parte, la frecuente identificación con el $\mathrm{Cid}^{67}$ coadyuva a equiparar la conquista de México con una cruzada, un argumento esgrimido tanto por Cortés, como por sus cantores, Lobo y Saavedra Guzmán, por ejemplo.

La suma de estas cualidades componen una figura acorde con el ideal antiguo, como ilustra esta estrofa donde la definición homérica del kaloskagathós introduce una paráfrasis de las virtudes éticas siguiendo a Aristóteles ${ }^{68}$ : "Mas unir a las armas el consejo / la prudencia al arrojo, el sesso al brío, / a la circunspección marcial manejo, / y a la docilidad el señorío" (VIII, 8). En cuanto al talante militar, requisito de cualquier conquistador, se trataría de una facultad innata en Cortés, según aclara el vate tras glosar su origen, estirpe y educación $(\mathrm{I}, 66)^{69}$ : "Por fuerza oculta, que en su pecho ardía, /... a la guerra, a la guerra se inclinaba: / ¡Oh impulso grande de la sympatía! / ¡Cómo ya el corazón le adivinaba, / que en la escuela de Marte había su acero / de ganar a su rey un mundo entero!".

Sin embargo, tal predisposición sólo deviene "virtud" si se ejercita bajo los dictados de la razón, de donde el concepto de heroísmo de raigambre aristotélica desplegado en pasajes como éste (IX, 77): "Pues ¿qué no hará señor de sus acciones, / quien alcanzó victoria de sí mismo? / predominio tan alto a las passiones... / de la heroyca virtud, la suma, el punto"; y en éste otro

${ }^{66}$ A propósito del complot contra el Héroe encabezado por Antonio de Villasaña dice el poeta (XII, 59 ss.): "Ya Julio César no dirá animoso, / que tal grandeza sólo en él assoma, / dando al fuego los pliegos jactancioso, / que contra él a Pompeyo embiaba Roma /...Y antes éste le excede, porque aquélla / no fue grandeza, sí ambición del trono". La soberbia de César es glosada en la influyente Filosofía moral derivada de la alta fuente del grande Aristóteles stagirita (1670) de Emanuele Tesauro: cf. VIII, 5, p. 108 (se cita por la traducción de Gómez de la Rocha, con varias ediciones en el XVIII, digitalizada en http:// books.google.com).

${ }^{67}$ Cf. VI, 68; IX, 5, 102; X, 21, 129; XII, 18.

${ }^{68}$ Cf. Iliada, IX, 443 (donde Fénix recuerda a Aquiles la máxima de su educación: "ser buen orador de discursos y hacedor de hazañas") y ARIsTóTELES, Ética a Nicómaco, II, 7, 1107a-1108b.

${ }^{69}$ Sobre Cortés escribe Gracián (El héroe, Primor IX): "Nunca hubiera llegado a ser Alejandro Español, y César Indiano... si no hubiera barajado los empleos: cuando más, por las letras hubiera llegado a una vulgarísima medianía, y por las armas se empinó a la cumbre de la eminencia, pues hizo trinca con Alejandro, y César, repartiéndose entre los tres la conquista del mundo por sus partes". 
donde tras definir al héroe "si menos que deydad, mucho más que hombre", continúa: "Éste de la razón nivel perfecto, / reglamento gentil del alvedrío, /...Es el fin del heroýsmo, y el objeto, / que con dominio del sentido, y brío, / encumbra al racional en quien impera, / a más sublime dilatada esphera"70.

La cumbre a la que todo héroe aspira, como recompensa de sus hazañas y refrendo social de su valía, no es sino la fama, una figura habitual en la epopeya que en la Hernandia proclama a sus campeones ya con su potente voz, como en Virgilio, ya con una fanfarria barroca, o con ambos instrumentos (I, 5): “... Cuyos ecos la Fama vocinglera / dio a sus clarines, porque su harmonía, / difundida al ambiente en nueva pompa, / fuesse animado aliento de su trompa" ${ }^{\text {"1 }}$. Por lo demás, este imaginario poético se conjuga con Aristóteles, de manera que si en la Ética a Nicómaco (I, 2, 1094b) la virtud es la verdadera felicidad y el deseo de gloria (philotimía) la virtud de los mejores ciudadanos, para Ruiz de León la fama, además de "la dicha mayor de los mortales" (VII, 2), constituye la "pasión" de los héroes (VI, 1-4): "En los hombres de espíritu elevado /...nacen conformes en tan igual grado / de la heroyca virtud, la fortaleza, / y el amor a la fama, que parecen / que unidos viven, y que juntos crecen. // Mellizos son del corazón gigante //...Noble ambición, la que gentil atiende / sólo a adquirir de la virtud la gloria, / abandonando, cuando la pretende, / preciosa vida, por mejor memoria”. Y aunque la virtud es un bien en sí misma, más allá de premios y honores -según expone en una digresión contraponiendo las enseñanzas de Séneca a las de Aristipo (XI, 6-12)-, en el caso de Cortés la sed de gloria se vio, finalmente, recompensada por el éxito, circunstancia significada por el poeta jugando con la etimología (VIII, 9): "Este Phénix, prodigio de la fama, / entre los héroes grave Polifemo, / a quien el orbe con razón aclama, / más que a Alexandro, que a Scipión, y a Remo"72.

70 XII, 4 s. Dice Tesauro (Filosofía moral, XVII, 5, p. 276): "Entre las Virtudes reguladoras de las pasiones la virtud heroica es la reyna; porque quien la posee se hace tan absoluto dueño de sus pasiones, que al modo de los fabulosos héroes, parecerá menos que Dios, y más que hombre”.

71 Cf. II, 11; IV, 39; V, 73; VI, 107. En la Eneida, la Fama es un monstruo alado, locuaz y sin trompa (IV, 173-188; 873). Según Vilanova (op. cit., pp. 295 ss.), el instrumento musical aparece en el Orlando (XXII, 93), de donde pasa a la Araucana (XVI, 1), deviniendo un lugar común.

72 A partir del apodo en griego del Cíclope: Polyphémos, "el muy famoso". Sobre la gratificación del heroísmo como regla ("Cabeza de Fidias") del buen gobierno se extiende en VI, 6-9, citando el ejemplo de Roma. 
Ahora bien, la fama debe contrarrestar los ataques de la envidia, su tradicional enemiga ${ }^{73}$, a la que se conmina a enmudecer (I, 9): "Calle también la embidia, cuya saña / perder intenta las plausibles glorias / de la siempre feliz triumphante España, / por usurparle al tiempo sus memorias: /...contra sí buelva, y en venganza grave, / nuevo Perilo con su industria acabe". La referencia a Perilo como paradigma de la envidia ilustra las complejas vías de incorporación de los motivos clásicos en la literatura barroca. En efecto, ya que el creador del famoso "toro de Falaris" fue la primera víctima de su cruel invención ${ }^{74}$, ejemplificaba la suerte de quienes reciben su propio castigo, caso de los perjuros en Ovidio y de los celosos en las comedias de Tirso de Moli$\mathrm{na}^{75}$. Por otra parte, la taxonomía de las pasiones de Aristóteles y el estoicismo donde los celos y la envidia constituyen subespecies afines facilita el tránsito del simbolismo erótico al ético moral presente en nuestro texto ${ }^{76}$. La peripecia de Perilo se corresponde, en fin, con la de esa Envidia que los latinos representaban como una monstruosa Gorgona o una vieja desdentada que termina devorándose a sí misma y, paradójicamente, enalteciendo a quien querría difamar ${ }^{77}$. A tal concepción remiten los pasajes de la Hernandia sobre esta vil pasión, frecuentemente aducida como causa de las dificultades del héroe, por ejemplo en esta estrofa donde el poeta lo nombra por vez primera (I, 61):
Era Cortés, ¡oh Musa! ¿Qué irritado numen, que opuesto a sí genio divino tuvo tanto héroe, para que penado, los rigores probasse del destino?
Esto es delirio, pues si fue embidiado, era fuerza correr este camino; que aunque vence el virtuoso, siempre lidia contra odio, contra engaño, contra embidia.

73 Cf. Horacio, Carmina, IV, 3. En el Peregrino indiano la Envidia y la Fama contienden en un sueño alegórico (XIV, 47 ss.).

${ }^{74}$ Esta máquina de tortura estaba ideada para que los gritos de los quemados en su interior semejasen los mugidos del animal (VALERIo Máximo, Dichos y hechos memorables, IX, 9).

75 Véanse, para el latino, Arte de amar, I, 650 y, para el dramaturgo, $L a$ prudencia en la mujer, II, 4 ("Perilo soy, pues su tormento imito / tejiendo celos por morir en celos"); Celos con celos se curan, III, 6 ("Perilo de sus tormentos / serán pues se martirizan / a sí mesmas").

${ }^{76}$ Respectivamente, Retórica, II, 12, 1388 b y Diógenes LAercio, VII, 111.

77 Cf. Ovidio, Metamorfosis, II, 760 ss., con quien concuerdan Alciato, Emblemas, 71 y RIPA, Iconología, 242. 
El tema es tratado prolijamente en el Canto IX (1-6) como introducción a las insidias contra el héroe en la Corte y la campaña de Pánfilo de Narvaéz, comisionado por Velázquez para apresarlo. Comienza así: "Por más que aguce venenoso diente ${ }^{78}$, / ciega a su enojo, cruel a su perfidia, / de la virtud al oro refulgente, / rabia tyrana de medrosa embidia: /...le da en el lustre sus mayores brillos // impossible parece que esta necia / pasión cobarde, siendo de tan corta / vista, que sólo ve lo que desprecia, / empañar quiera lo que no soporta". Continúa diciendo: "A lo grande herirá su saña dura, / no a lo supremo, que anda en más altura"79; de donde: "Felicidad será ser embidiado", máxima ésta que recoge la opinión común entre los antiguos de que la envidia "ataca a las cumbres" y, por lo tanto, "aumenta la fama" ${ }^{80}$. Así pues, la animadversión de Diego Velázquez hacia Cortés -análoga a la de Julio César hacia Catón según el exemplum que cierra este preámbulo ${ }^{81}-$, al aquilatar la virtud de extremeño, redundaría en beneficio de su empresa.

Más aún, las luchas intestinas entre los españoles no escapan a la providencia de Dios, idea expresada mediante la metáfora de la "música del universo", en cuya armonía de notas concordantes y discordantes está cifrado el sentido último de los acontecimientos (IX, 51-57): "Admirable es del Hacedor increado / el sumo acierto, con que igual dispone / todas sus obras, para que templado / su concierto, otra música ocasione: //...Instrumento es el orbe, en que plausible / con dulces contrapuntos diferentes, / se escucha la sonora melodía, / que hace en varios acasos harmonía". En consecuencia: "Obedeciendo así sacro artificio / oculto al mundo, corre presuroso / Pámphilo de Narváez, al exercicio, / que ha de corresponder allá harmonioso". Aunque Aristóteles atribuye esta imagen a Heráclito, en la Antigüedad solía asociarse con Pitágoras, conociendo numerosas recreacio-

78 El mismo tópico aparece en VII, 64, 69. El "diente de la envidia” está en Horacio (Carmina, IV, 2).

${ }^{79}$ Según Platón (Fedro, 247b), las almas más nobles ascienden hasta devenir inalcanzables incluso para la envidia de los dioses, y respecto a los héroes escribe Tesauro (Filosofía moral, XV, 6, p. 223): "A los que aman la Honra llegan a tal grado de virtud con las acciones heroicas que la Malevolencia se enamora de ellos y la Invidia desespera totalmente de igualarlos".

${ }^{80}$ Expresiones de Ovidio (Remedios contra el amor, 370, 389).

${ }^{81}$ Más adelante $(I X, 82)$ la magnanimidad de Cortés hacia Narváez se equipara a la de Mitrídates con Natano, anécdota comentada por TESAURo tras referirse al antagonismo entre César y Catón (cf. Filosofía moral, VIII, 5, pp. 108-109). 
nes en la tradición europea a partir del Renacimiento, de entre las cuales nuestro autor más que la "inmensa cítara" de fray Luis de León, quizá tuviese en mente el "órgano cósmico" del jesuita Athanasius Kircher ${ }^{82}$.

El papel de la Providencia, por su parte, suscita el problema del destino y del libre albedrío; esto es, de los márgenes de acción humana en un orden cuya lógica no siempre resulta inteligible sino caprichosa, un concepto que en la tradición helenístico-romana personificaba la diosa Fortuna. Las implicaciones éticas de esta cuestión fueron abordadas primero por Aristóteles, quien partiendo de la voluntariedad de la virtud, consideró la felicidad no como efecto del azar sino el premio del esfuerzo, y luego por el estoicismo, de cuyo intento por conciliar el destino con la responsabilidad individual da cuenta el conocido adagio: "la Fortuna ayuda a los audaces" ${ }^{83}$. A esta cosmovisión, obviamente cristianizada, responden afirmaciones de nuestro poeta como que "nada de valde ha dado... / la Fortuna también tiene sus leyes" (I, 28), "la Fortuna siguiendo las estrellas / hace la suerte y suele no acabarla" (XI, 105), o que el mérito es "saber labrarse / con el propio sudor sublime assiento" (XI, 5-6). Gracián, por su parte, considera el valor y la fortuna los ejes de la heroicidad y, a propósito del emperador Carlos, añade que la victoria suprema consiste en servirse de la fortuna y, al cabo, triunfar sobre ella, argumentos que resuenan en esta caracterización programática $(\mathrm{I}, 3)^{84}$ :

Las armas canto, y el varón glorioso, que labrando a sus manos su oportuna

82 Cf. Ética a Eudemo, VII, 1, 1235a. En el libro VIII de la Musurgia Universalis sive Ars Magna consoni e dissoni (Roma, 1650), la lámina del "Organo cósmico" (t. 2, pp. 366-367) tiene la siguiente leyenda: Harmonia nascenti mundi. Sic ludit in orbe terrarum aeterna Dei Sapientia. Véase también GRACIÁN (El criticón, primera parte, crisis primera): "Sola la infinita sabiduría de aquel supremo hacedor pudo hallar el modo, el orden y el concierto de tan hermosa y perenne variedad".

${ }^{83}$ Cf., en un caso, Ética a Nicómaco, I, 7-8, 10967a-1099b; III, 6, 1115a-b, y, en el otro, Eneida, X, 284 (Audentes Fortuna iuvat) y SÉneca, Medea, 159 (Fortuna fortes metuit, ignavosque premit).

${ }^{84}$ En El héroe, Primor X y Primor XI. Véase este otro paralelo en $\mathrm{El}$ peregrino indiano (I, 15): “¡Oh, famoso Cortés, Cortés divino, / gloria del Nuevo Mundo, y patria nuestra! / cómo haciendo al valor ancho camino, / con mano poderosa y fuerte diestra, / a pesar de fortuna, y su destino, / diste de su valor tan clara muestra, / surcando el ancho mar del Ocidente, / quedarte eternizado entre la gente". 
suerte, constante, diestro, generoso, sobre los Astros erigió su cuna:

Héroe christiano del valor colosso, que triumphó del destino, y la Fortuna, de sus proezas blasón, de España gloria, campeón insigne, de inmortal memoria.

Por lo demás, la victoria de Cortés sobre la fortuna atañe a uno de los principales ejes de la Hernandia: el conflicto entre la Providencia, que ha resuelto extender la fe verdadera al conjunto del orbe, y la superstición encarnada por Lucifer. En efecto, las fuerzas diabólicas representadas en Europa por el protestantismo, predominan en el territorio allende el océano que el héroe ha de ganar para Dios y el emperador, donde se rinde culto a la fortuna, según se discurre en el prólogo del Canto III (1-9) asimilando las creencias de los mexicanos con las grecorromanas. Comienza así: "Entre los falsos dioses, donde agrega / supersticiosa infiel mythología, / yerros a yerros, fabricando a ciega / deydades de su propia fantasía... // Uno fue de éstos la deydad mudable / de la ciega Fortuna... / Jano de lo próspero, y adverso, / el arbitrio mayor del universo". Y, a continuación, traza el retrato de esta divinidad, probablemente inspirado en Baltasar de Vitoria ${ }^{85}$ :

En pie sobre una esphera la pintaban, en la diestra una fértil cornucopia, adelfas la siniestra azibaraban; ¡rara contradicción, no en ella impropia! felicidad las rosas denotaban: la escasez triste en el axenxo apropia, y el globo en leve punto vacilante, de su inconstancia siempre lo constante.

Más adelante, el fatalismo supersticioso de los súbditos de Moctezuma explicaría la identificación de los españoles con los dioses mencionados por las antiguas profecías, un lugar común de la literatura cortesiana que aquí cuestiona el valiente Xicoténcatl sirviéndose del imaginario clásico (III, 29-32): "¿Por venir de la Aurora sus fanales, / se ha de juzgar que son los Orientales? // Essos raros embreados paladiones, / que asustan nuestras

${ }^{85}$ Compárese III, 3-4 con Segunda parte del Teatro de los dioses de la gentilidad, VII, 1 (pp. 477-479 de la impresión barcelonesa de Juan Piferrer [1722], digitalizada en http:// books.google.com). 
costas con espanto //...Estos advenedizos estrangeros / (si a la verdad no son monstruos marinos, / o Centauros de Tetis, que guerreros / nuestros mares infestan peregrinos...)"86. E igual ocurre con la visión premonitoria de Alchohua, el sacerdote de Tlácl, sobre la caída del imperio (IV, 43):

Zozobró en cristalino monumento

el palacio, que Apolo a gyros dora, el amphitheatro, de Mavorte assiento, el jardín cyprio, que matiza Flora, el panteón, que Neptuno sube al viento, el blando alcázar, que Amphítrite mora, el imperio de la India inaccessible:

México naufragó. ¡Dolor terrible!

Además de la común creencia en los augurios, los mexicas compartían otros ritos con el paganismo antiguo, caso del culto a sus reyes difuntos ${ }^{87}$ o de los esponsales, donde el novohispano introduce una comparación diferente a la de su fuente histórica $(\mathrm{V}, 95)^{88}$ : "En algunas costumbres semejaban / a otros antiguos; pues sus matrimonios / eran como los ritos, que guardaban / los athenienses, y los macedonios".

Pero las afinidades entre la Antigüedad y el imperio azteca no atañen sólo a la religión, sino a otros usos e instituciones; de ahí que, por ejemplo, se mencione la "República" de Tlaxcala y el "Senado" de los "patricios" y "tribunos" 89 . No obstante, los "nobles mexicanos" que ya en astucia política, ya en bravura y pundonor igualan, cuando no superan, a los antiguos ${ }^{90}$, suelen

86 Clementina Díaz y de Ovando, “Tlaxcala en la épica y en la dramática de la Colonia”, AIIE, 19 (1951), pp. 69-71, percibe atisbos de conciencia criolla en el parlamento del joven Xicoténcatl. Para el adivino tlaxcalteca, en cambio, "Hijos de Apolo son... / Él los hace inmortales cuando nace" (III, 54).

$87 \mathrm{Al}$ respecto comenta $(\mathrm{V}, 107)$ : "Chapoltepec, montaña deliciosa, / elevaba el panteón, que la ceniza / de sus coronas guarda magestuosa, / en vasos de oro, donde se eterniza: / Troya discreta, Roma religiosa / Lo mismo hicieron; con que no horroriza, / que en aquesto sobervios se despeñen, / si tienen tales sabios, que lo enseñen”. Sobre la divinidad de Moctezuma, véase I, 49.

${ }^{88}$ En el pasaje correspondiente, Solís alude, en cambio, a los Lares romanos: cf. Historia de la conquista de México, III, 17.

${ }^{89}$ Véanse III, 43 (República); III, 18, 27, 35, 58, 62; V, 62; VIII, 69; XI, 38, 43, 47, 81, 84, 85; XII, 9, 60 (Senado, senadores).

${ }^{90} \mathrm{X}, 62$. Tras la derrota de Otumba, Huahtemucht finge rechazar el trono azteca, como en circunstancias análogas hizo Tiberio (XI, 42), según 
ser apodados "bárbaros", helenismo de uso corriente para los indígenas en las epopeyas americanas ${ }^{91}$. Tales anacronismos contribuyen a exaltar la gesta de Cortés -"tan grande Conquista, que al Imperio / Romano ha de causar pasmo, o afrenta" (I, 116)-, y, a la vez, desacreditan la visión primitivista del Nuevo Mundo y, en particular, la del "buen salvaje" mexicano difundida por fray Bartolomé de las Casas, la cual, en cuanto sustento de la "leyenda negra", había sido combatida por Solís. Ruiz de León se hace eco de este debate historiográfico ya en los preliminares (I, 10): "No eran, como los finge, desvalidos / miserables los indios, y desnudos, / pues la malicia los halló advertidos, / si acaso fueron al cultivo rudos" 92 .

Respecto a Moctezuma -"este tyrano gobernaba cuando / los españoles, con destreza suma, / a la tumba de Apolo registrando, / cortaron del Atlántico la espuma" (V, 64)-, aunque encarne al "mal salvaje" luciferino de la Hernandia", el poeta no oculta la bondad de sus leyes y tribunales, aderezando la información extraída de Solís sobre las instituciones aztecas con alusiones circunstanciales a la historia y la mitología antiguas (V, 87-91): “¿Cuál govierno miró con tanto empeño / entre gentiles, leyes tan notables, / fueros tan justos, tan puntuales penas? / No hicieron más infantes, Roma, Athenas. //...Éstas hicieron guardar con entereza; / ni la industria, ni el cohecho halló sagrado, / al fiel de Astrea, dieron con pericia, / zelo, equidad, prudencia, honor, justicia //...De jueces inferiores apelando, / pasaban otras causas al severo / Tribunal de Justicia, sentenciando / sabia Némesis invariable fuero".

un pasaje de Tácito comentado por Gracián (El héroe, Primor II) y SaAveDRA FaJARdo (Idea de un príncipe político cristiano, Primor XVII). En XI, 83 el anciano Xiconténcatl, resuelto a dar muerte a su propio hijo, se asimila al cónsul Manlio Torcuato (Livio, XXII, 60).

91 Véanse I, 41; II, 15, 17, 29, 75; III, 49, 52, 98, 99; V, 43; VII, 103; X, 25, 58, 117; XI, 94, 133; XII, 22, 34, 60, 98.

${ }^{92}$ Insiste sobre ello en V, 87: "Diga el Nación, mirando este disseño / cierto, aunque inculto, si eran miserables / humildes y desnudos”. Por otra parte, "aventajaron a Apeles sus pintores" (V, 67).

93 Según M. Peña, "Luces dieciochescas...", pp. 127-128. El poeta lo tacha de "monstruo sobervio" $(\mathrm{V}, 60)$, apuntando a la etimología ya razonada a propósito de su homónimo "Moctezuma el primero, cuyo empeño / fue confirmar su nombre de arrogante, / pues es lo mismo, que el que ve con ceño: / Emprendió su sobervia, del tonante, / como del mundo coronarse dueño" $(\mathrm{V}, 56)$. 
La demonización del indio, que al legitimar la Conquista como evangelización, sienta las bases de una identidad cultural y política simbolizada por la monarquía, coexiste en la Hernandia con la exaltación de la tierra natal, que proyectando en el presente la antigua grandeza de México, reivindica su centralidad en la España imperial ${ }^{94}$. A este marco ideológico, más que al pleno desarrollo de la conciencia criolla, cabría referir las descripciones de las riquezas y bellezas naturales del país, que Ruiz de León va intercalando en el decurso narrativo con frecuentes reenvíos a la cultura clásica. Para empezar, acentúa la relevancia científica del Descubrimiento, que desmintió la teoría, sostenida por Estrabón, Plinio o Tolomeo $(\mathrm{V}, 4)^{95}$, de las zonas inhabitables de la Tierra:

Callen confusos el egypcio, y griego, que creyeron del hombre inhabitable la tórrida mansión, que embuelta en fuego, fue a su geógrapho estudio impenetrable; de la aurora risueña el suave riego, con ambiente sereno, por ella hable, viendo quanto convence la experiencia, errados juicios de falible ciencia.

La nueva ciencia, no obstante, se compagina con la antigua mitología en el preámbulo del Canto V, donde se fijan las coordenadas geográfico-astronómicas de la "tórrida zona" ocupada por México, a partir de las constelaciones celestes (2-10): "el Cancro fogoso, estival llave, / colocada por Juno en la alta esphera, / le hace bolver atrás, y lo violento / perficiona su curso, y lucimiento... Del Equador esquivo retirada / entre el flamante Can, y Ursa de yelo, / en diez y nueve grados colocada... Nutriz de Jobe, o fuesse transformado / por tifón al zodiaco luciente, / caudato Capricornio, iluminado / el influxo le dexa a lo ascendente: / Tauro, y León, en el aspecto iguales, / en graduación están de verticales... Por Levante al Atlántico se extiende, / de

94 Sobre este rasgo de la épica novohispana véase E. B. DAvis, op. cit., pp. 129 ss. Según PEÑA ("Luces dieciochescas...", p. 129), el orgullo mexicano de Ruiz de León sería "inconsciente nacionalismo".

${ }^{95}$ Las Casas (Historia de las Indias, VI) y López de Gómara (Historia general de Indias y vida de Hernán Cortés, III) dedican sendos extensos capítulos a la discusión de sus teorías, asunto inexistente en Solís. 
Annian las ondas a occidente mira, / a la Virgínea con el sur comprehende, / y a Pánuco antes por el norte gyra" 96 . Tal configuración astral explica la benignidad climática: (7) "Suave Fabonio, con marea templada, / mitiga los bochornos de su buelo, / tal, que del clima puede, a beneficios, / cambiar en equinoccios los solsticios"; (8)... "El que de Chypre fue copo nevado, / la predomina con benigna frente" 97 .

Una vez situado el país en el mapamundi, Ruiz de León acomete la descripción de Tenochtitlán, un topos de las crónicas rimadas e históricas de la Conquista, entre ellas la de Solís a quien verosímilmente resume ${ }^{98}$. Además de numerosos cultismos y tecnicismos extemporáneos ${ }^{99}$, no faltan referentes prestigiosos tanto para la capital -"No se jacte Venecia decantada, / que a Neptuno su histriada cuna debe, / que México Imperial, más celebrada, / en mejor golfo de cristal se mueve"-, como para sus monumentales edificios -"Gigantes del ayre"-, caso del primero de los seis palacios de Moctezuma, parecido al laberinto: "Era el uno tan raro mausoleo, / que el tamaño, y sobervia que lo traza, / assombro fuera del galán Teseo, / y en él por su hilo no saliera a plaza"100. Pero por encima de estos colosales monumentos descuella la "Alegre Primavera en sus jardines: / de Flora, y Amalthea la permanencia, / hace que Invierno no hallen sus confines". Así pues, la belleza y feracidad de estos vergeles superan a los más celebrados por los poetas de la Antigüedad -"Marchitos queden quantos de Pomona, / cultivados pensiles el Pangeo, / florido ostenta, cuando los corona / la cipria diosa, del feliz Hybleo: / calle el ámbar fragante, que blasona / Pancaya, fértil del sudor sabeo"-, ya que en ellos la naturaleza supera al arte, de manera que, cual "Galán Narciso... es

96 Sobre la metamorfosis astral del cangrejo enemigo de Hércules, véase Eratóstenes, Catasterismos, XI; Amaltea y Pan, los personajes alegados para el origen de Capricornio, aparecen en Higino, Astronomía, XIII, 4.

${ }_{97}$ Pasajes citados: V, 7; 10. "El copo nevado" de Chipre es céfiro, el viento que llevó a Afrodita hasta su isla. La imagen recuerda el florido pensil de Gracián, "Verde Chipre", donde soplan Céfiro y Favonio y "estaba la Primavera deshilando copos en jazmines" (El criticón, primera parte, crisis XII).

98 Compárese V, 12-42, 65 ss. con la Historia de Solís, III, 13 ss.

99 Por ejemplo, "Corinthia Estofa" (V, 18); "Y en triglifos, metopas, y follage, / Lisipo halló de su Sincel ultrage" (V, 28).

100 Véanse, sucesivamente, V, 13; 66. De la imagen de Huitzilopochtli, dios asimilado a Marte, se dice que "Vibra en la mano sierpe vandolera, / que en otro tiempo persiguió a Latona" (V, 33), aludiendo al episodio de Pitón narrado por Higino (Fábulas, CXL). 
su misma hermosura quien le mata"101. En consecuencia, en América y en México hay que localizar los paraísos imaginarios de la mitología (42):

¡Con qué verdad cosmógrapho acertado, al atlántico mar descubrió cierto el hyperbóreo sitio, que templado paraíso fue de americano puerto! En esta amenidad, en este prado, mora de las hespérides el huerto; creíble es de sus manzanas el thesoro, en tierra, que produce montes de oro.

La octava anterior ilustra el bucolismo que impregna los paisajes de la Hernandia, con notables paralelos en la Rusticatio mexicana de Rafael Landívar, escrita en latín y considerada las Geórgicas del Nuevo Mundo ${ }^{102}$. Singularmente plásticas resultan las descripciones insertas en el itinerario del ejército de Cortés entre Cozumel y la capital, por ejemplo el valle del Atoyac -"indiano Nilo"-, o la región de Amecameca y Nepantla, apodada "Arabia feliz... del Phénix oloroso nido", refiriéndose a sor Juana Inés ${ }^{103}$. Aunque el poeta podría haber visto algunos de estos lugares, es evidente el peso de la tradición poética y en particular de la Sicilia cantada por Virgilio y, en su estela, por Góngora y Lope ${ }^{104}$. Tal es el modelo recurrente de un paisaje dominado por volcanes como el Popocatépetl -el "humeante" en náhuatl-, de cuyo azogue los españoles fabrican pólvora (III, 70) ${ }^{105}$ :

101 Cf. V, 36 ss. La fértil Cuba es un "Pensil hybleo" (I, 23), en referencia al monte siciliano cantado por Virgilio (Bucólicas I, 54; VII, 37). Cholula, por su parte, está adornada por la "Cornucopia de Amalthea" y excede "los quadros de Pomona" (III, 77).

102 Así, M. Peña, "Poesía épica”, p. 275; "Luces dieciochescas...”, pp. 126 ss. LANDívar, que compuso y publicó el poema en Italia, tras la expulsión de la Compañía, había residido en México entre 1749 y 1761. Ya que enseñó latín y gramática en el Seminario de Puebla, pudo conocer a Ruiz de León, a quien cita entre los poetas novohispanos ilustres: cf. Rusticatio mexicana, I, nota 11 al v. 287.

${ }^{103}$ Véanse III, 79; VI, 42-48.

104 Sus viajes y cambios de residencia cuestionan la presunción de Menéndez Pelayo de que "hubiera pisado siquiera la tierra que describe" (op. cit., t. 1, p. 81).

${ }^{105} \mathrm{Al}$ mismo volcán alude en XI, 32: "Ni de Tinacria, promontorio altivo, / ni de Quito, peruano mongivelo, / gargantas por adonde Lethe esquivo, / con avenidas de humo empaña el cielo". Curiosamente, esta vulcanografía más que con Solís (cf. III, 9) concuerda con la Historia general de las cosas de 
Su cumbre enseña, con tostadas ramas, un volcán, cuyo nombre más le vino, que a Eolia, Licia, y Sicilia por las llamas del Lypara, Chymera, y del Pachino: aquí, entre algosas sulphurantes lamas, de Flegetonte descubrió el camino el atrevido Ordaz, quando valiente al azufre le extraxo a su corriente.

En el territorio de Tlaxcala destaca, en fin, el Cuatlapanga, el "cabeza partida" de los indígenas y, según el poeta, "indiano Atlante", que oprime "quantos prados ha pintado Flora, / todo el imperio donde Ceres mora", y "septentrional Parnaso, donde toca / músico Apolo, cítara cadente", cuya grandeza superlativa no tiene parangón ${ }^{106}$ :
No de Sicilia tosco Lylibeo;
no de la Macedonia Olympo grave;
no de la Tracia célebre Pangeo;
no de Fenicia el Lýbano se alabe, que más que éstos, que el arcado Lyceo, que el Ripheo scita, sólo en éste cabe, fuego, verdor, maleza, horror, frescura, porque hasta su fiereza es hermosura.

\section{Las Horas mitológicas}

Las prosopopeyas de las estaciones del año y las horas del día constituyen uno de los principales topoi virgilianos de la poesía hispánica desde el Prerrenacimiento, que en la épica sirve para encuadrar la acción y ennoblecerla, de ahí su presencia regular en los cantos y sus divisiones internas ${ }^{107}$. El tratamiento de este hito narrativo en la Hernadia demuestra no sólo la erudición clasicista del autor, sino su dominio de la astronomía, la gran ciencia de su tiempo ${ }^{108}$. Aunando ambos saberes data, por ejemplo, la Nueva España (XII, 12) de Bernardino de Sahagún, manuscrita hasta el siglo XIX.

${ }^{106}$ Cf. VI, 13-19.

107 Al respecto, MARía Rosa Lida, "El amanecer mitológico en la poesía narrativa española", La tradición clásica en España, Ariel, Barcelona, 1975, pp. 119-164; para la épica novohispana, PIÑERo, art. cit., pp. 179-180.

${ }^{108}$ En 1637 se instituyó la primera cátedra de Astrología y Matemáticas en la Universidad de México, que ocupó Sigüenza y Góngora a partir de 1672. 
las primeras incursiones españolas en el litoral mexicano (I, 22): "Contando Delio al gyro presuroso, / que el primer moble en curso ha devanado, / del Sol, que en Virgo disfrazar promete / años mil y quinientos diez y siete”. Dos años más tarde zarpó Cortés, cuando (I, 75): "Doraba el Sol al Escorpión helado, / que si es casa de Marte belicoso, / pudo, quedando de oro iluminado, / lucir benigno influjo más piadoso" 109 . A la simbología mítico-astral se recurre, de nuevo, para el inicio de la campaña final contra los aztecas, en mayo de $1521^{110}$, mediante un elaborado circunloquio, donde la celebración del mes sirve, a la vez, para homenajear a Góngora, cuyo conocido arranque de la Soledad Primera parafrasea su émulo novohispano (XII, 108 s.):

Gozaba el año su estación florida, o ya estival, según la considera Chronógrapho patricio ${ }^{111}$, a la medida, que en su eclíptica Febo reverbera: cuando rota la yema entumecida, buelve rubí, lo que esmeraldas era, y blancas sienes Amalthea corona, del cultivo fragante de Pomona.

En el purpúreo tiempo delicioso, Galán Narciso de argentada plata, Adonis tierno del boscage umbroso, que a uno viste, y en otra se retrata: en el de Ceres, Benjamín gracioso, en la flor de los meses, en la grata era de Venus, de Cibele ensayo, en lo mejor, en Primavera, en mayo.

A veces, el atlas del cielo marca el tiempo de un suceso concreto, por ejemplo, la batalla de Cempoala ${ }^{112}$. La noche y la lluvia caen sobre el campamento de Narváez, que espera ansioso la llegada de Cortés (IX, 93 s.): "Hasta que huyen los dos de

109 Otros ejemplos para estaciones y meses del año: V, 2; IX, 93-94; XI, 125; XII, 67.

110 En ocasiones las coordenadas mitológico-astrales marcan la duración de un suceso: II, 58; VIII, 89; X, 79; XI, 101; XI, 137; XII, 46-47, 97. En XII, 34 la coincidencia del fin de la Conquista con el horóscopo imperial se considera obra de Dios.

111 El aludido podría ser Alonso de Santa Cruz, cosmógrafo de Carlos V, que corrigió las cartas de navegación a partir de las variaciones del campo magnético en la Nueva España.

112 Véanse, además: II, 58; VIII, 89; X, 79; XI, 137; XII, 46-47. 
las cabrillas / el susto, y buscan, abreviando el passo, / éste su aloxamiento, aquél su ocaso //...En la casa de Tauro, nebulosa / Mérope, llora trémulas amantes / por Sísipho desdichas que no enjuga, / y a esconderse melárchica madruga"113. El extremeño se presenta con su ejército cuando "Ya las Hyadas miraban la bocina, / en el medio silencio más pesado" (101). Finalmente, el resplandor rojizo del sol naciente señala la derrota de Narváez: "El rosicler de Delio presuroso / madruga a festejar tanta victoria"114.

Más frecuentes aún son las personificaciones de las horas del día, donde la mitología se reviste de metáforas inspiradas en los grandes poetas áureos, en particular Góngora y Lope de Vega. Entre los amaneceres de nuestro corpus destacan aquellos donde el poeta significa los cambios de coloración, aludiendo ya a la progenie del Titán Helios, ya a Febo-Apolo ${ }^{115}$. Así, la luz lechosa y fría de la doliente Aurora, cuyas lágrimas forman el rocío, se torna dorada a la llegada de Apolo con los primeros rayos del sol (VI, 77 s. $)^{116 .}$

La amante de Memnón arrebujada con púrpuras, y armiños, melindrosa en el plaustro de nácar recostada, corona ya sus blancas pías de rosa: soñolienta bosteza derramada de margaritas copia tan preciosa, que dando al prado tanto con verterlas, sólo al ostro, y botón les fue de perlas.

113 Las cabrillas son las siete Pléyades, una de las cuales, Mérope, es invisible por estar casada con un mortal, Sísifo, y ser cómplice de sus fechorías. Forman parte de la constelación de Tauro, en cuya cabeza se sitúan sus hermanastras las "pluviosas" Híades (Eneida, I, 744). Al respecto, véase Eratóstenes, Catasterismos, XIV; XXIII.

114 Cf. IX, 111. El "rosicler del día" aparece en la dedicatoria del Polifemo (v. 9) y deviene una imagen corriente entre los culteranos: Vilanova, op. cit., pp. 167-171.

115 II, 35 s. ("La esposa de Titón, en el oriente / se assomaba parlera, al lecho ufana //...Del flamígero carro del blanco Etonte / uncido a la coyunda reverbera, / la línea hollando que midió Faetonte / quando atrevido requirió la esphera”); X, 1 ("Apenas el pintor de la mañana /...va metiendo colores de oro, y grana / a los bosquexos que dexó la aurora”). Véanse, además, I, 132; VII, 39; VIII, 30; IX, 111; XI, 12.

116 En las Metamorfosis de Ovidio (XIII, 579 ss.) Eos, la madre amorosa de Memnón, saca su cadáver del campo de batalla. Sobre el Apolo pastor de Admeto, rey de Feres: Apolodoro, Biblioteca, III, 10, 4; Higino, Fábulas, L. 
Con su menudo aljófar transparente matizados pensiles de escarlata, también adorna México luciente, a la función, que prevenido trata: salta el pastor de Admeto, y en la gente, éste dando oro, como aquélla plata, y colores la luz, en breves horas amanecer se vio con dos auroras.

Los amores de Selene y el durmiente Endimión evocan la placidez del ocaso y la llegada de la noche (VIII, 15) ${ }^{117}$ :

Por repetir al Lathmio sus querellas, se assomó melindrosa, e importuna, a ver amante de Endimión las huellas, plateando montes, argentada luna; saludan su venida las estrellas, blancas exalaciones en su cuna la festejan, templando con beleño, música muda, que concilie el sueño.

$\mathrm{Y}$, sin embargo, la presencia de los dioses infernales tiñe el momento de connotaciones terribles en la estrofa que introduce el congreso de nigromantes (IV, 34): "Hora era ya, que huyendo la alegría / al transtornarse de Faetón el coche, /...Y desprendiendo Proserpina fría / el capuz, con que ateza obscura noche, / a los del firmamento ojos errantes, / los hizo con el opio palpitantes".

\section{ESCENAS DE GÉNERO}

El precepto horaciano de "enseñar deleitando" justifica la presencia de episodios que interrumpen o engrandecen la narración épica, dotándola de variedad -catálogos, asambleas, descripciones de armas, historias de amor, excursos mitológicos, etc.-, cuyo canon fue fijado por Virgilio en la Eneida a partir de Homero y ampliado por Lucano con digresiones eruditas ${ }^{118}$.

117 Cf. Apolodoro, Biblioteca, I, 7, 5-6. En otros atardeceres intervienen Apolo y/o Faetonte: VII, 97; VIII, 12; XI, 35.

118 Cf. Epistola ad Pisones, vv. 334; 343. Según Aristóteles (Poética, XVII, $1455 \mathrm{~b}$ ), la función principal de los episodios es extender la trama simple de las epopeyas. 
Entre los más imitados se cuentan las descripciones del infierno, la tempestad y los juegos, así como las escenas de batalla, objeto de este apartado.

La "maquinaria sobrenatural" de la epopeya no se agota en la tramoya mitológica, y menos aún en poemas como la Hernandia donde conquista y evangelización van de la mano. De hecho, nada más arribar a Cozumel, el héroe empieza "con desprecio de Lethe, a quien da espanto, / a introducir el evangelio santo"119, lo que se traduce en la primera misa, cantada en un templo indígena profanado para consagrarlo a María, y en la consiguiente cólera de Satanás (I, 132) que "Al irse sus estatuas deshaciendo, / se estrelló en el profundo, rebentando / porque su magestad iba perdiendo". Así pues, el Ângel del mal reúne en conciliábulo a las fuerzas de la idolatría, conminándolas a emplear toda suerte de ritos nigrománticos, augurios, visiones y prodigios ominosos para lograr que Moctezuma continúe siendo el "Argos" del satánico imperio, tema sobre el que versa íntegramente el Canto $\mathrm{IV}^{120}$.

Como preámbulo se ofrece la descripción del Infierno, cuyo modelo tradicional antes que el descenso al Hades del Canto XI de la Odisea, fue su recreación en el Averno de la Eneida ${ }^{121}$. Con todo, Ruiz de León sigue a Ovidio en la entrada de la gruta "que vivo, sólo pudo el Tracio, / llegar a profanar, con loco empeño, / su tenebroso umbral, pues se defiende, / al par que a todos recibir pretende", para luego, tras los pasos de Virgilio, arribar a "Aquel valle, región que el Sol no zela, /...centro de confusión, de llanto escuela, / cárcel, donde se muere, y no se espira, / lugar de pena, susto, y mal eterno; / nada es más que su nombre: el propio Infierno"122.

La aparición de Satanás conmociona a los moradores de su reino, escena donde el novohispano acredita no sólo la estética barroca del horror y la fealdad, sino también su bagaje mito-

119 Compárense estos versos (Canto I, octava argumental) con los de Sigüenza y Góngora (Primavera indiana, XXI): "Carlos a quien Cortés, detente mano, / venera el nombre que al Leteo espanta".

${ }^{120}$ Cf. IV, 67. Argos es el fiel centinela de Juno, la enemiga del héroe en la Eneida, papel desempeñado aquí por Lucifer. De hecho, en un espejismo de Moctezuma se alude a su metamorfosis en "galán pavón" (IV, 72).

${ }^{121}$ La influencia de sus secuelas alegóricas en Dante y, sobre todo, en Tasso, es patente en SAavedra GuzMán (El peregrino indiano, IX, 112 ss.) y Loвo (Mexicana, I, 10 ss.): véase Piñero, art. cit., p. 176.

122 Compárese con Metamorfosis, X, 10 ss. (Orfeo y Eurídice) y Eneida, VI, 235 ss. 
lógico. Como botón de muestra sirva este extracto (VI, 1-20): "Soltó Charón la horríssona bocina, /...el barco zozobró... / el imperio tembló de Proserpina, / y de la Estigia la rapante escama / de dragones... / por las ondas sacaron las cabezas. // De Minos bambaleó el palacio fuerte, / y temió en Flegetón llegar a hundirse, /...Tesífone largó, por encubrirse //...Encogiose el Cervero estremecido, /...hundiose la Chymera en el olvido, / y la Syrena, que por Circe pena, / enmudeció; las Gorgonas horribles, / a tanto horror, quedaron insensibles // Huyeron los bimembres al amago, /...La Hydra escondió sus frentes en el lago, / quedó Clotos immoble a tal estrago; / Tántalo estuvo nueva sed bebiendo, //...En pie la novedad puso a Teseo /... Suspendiose el castigo en Salmoneo, /...Phedra calló, calló también Ceneo; / Eriphile pausó llanto vehemente; / y del tartáreo los severos manes / temieron otro asalto en los titanes. // Volvió Phlegias el rostro macilento /...Cessaron las Bellides del tormento: / el cerdoso copete, con que al viento / infesta en sierpes... / ciega Discordia, más atosigado / quedó en lúbricos cuellos erizado" 123 . A todos ellos, anuncia Satanás la llegada de Cortés, el enemigo que "A hollar viene sobervio los altares, / que en perfumes, e inciensos nos dan cultos /...Y con el cedro, que al cocito sella, / nuestra cerviz quebrantará su huella”.

El afán por emular a Virgilio explica, asimismo, la relevancia en el ciclo cortesiano, sobre todo en la Mexicana, de un suceso de escasa entidad historiográfica, la agitada travesía de la flota entre las islas de Cuba y Cozumel ${ }^{124}$. Con todo, el cotejo del episodio de la Hernadia con su correspondiente en la Eneida evidencia, por una parte, la dificultad para dilucidar si Ruiz de León mira al Mantuano o a alguno de sus imitadores y, por otra, el venero culterano, patente en el vocabulario y los recursos de estilo.

Mientras en la Mexicana, al igual que en la Eneida, la tempestad obedece a la enemistad de un dios -Neptuno, aliado de Plutón, y Juno, respectivamente-, nuestro poeta se limita a señalar (I, 92): "bogan el undoso / piélago, en donde dura lona vue-

123 Cf. IV, 11-16. La mayor parte de estos personajes comparecen en la Eneida, VI, 360 ss., pero algunos como las Bélidas -las Danaides griegas, mencionadas asimismo en II, 34- proceden de Ovidio (Metamorfosis, X, 44). Sobre éstos y otros súbditos de Plutón discurre extensamente BALTASAR DE Vitoria (Primera parte del Teatro de los dioses de la gentilidad, IV, 5 ss.).

${ }_{124}$ Mexicana, I, 33-II, 4-28. La tempestad de la Eneida (I, 81-157) depende, a su vez, de Odisea, V, 281 ss. Entre sus varias recreaciones en la épica hispana destaca la de Ercilla: véase Araucana, XV, 56-XVI, 19 y el comentario de Vicente Cristóbal, art. cit., pp. 79-83. 
la / tan veloz, que sus quillas juzgó graves / Neptuno, tal vez nubes, tal vez aves". No obstante, en todos los casos, el estallido del meteoro compete al señor de los vientos: "Eolo desata de su gruta opaca / el voluble escuadrón, que en silvos roncos / rompe los montes, con que más lo atraca, / y escollos parte, cuando vuela troncos" ${ }^{\prime 25}$. En la siguiente estrofa, cobra protagonismo el viento del norte: "Brama helado Aquilón, y con nublados /... dexa con negras sombras anegados / la tierra, el mar, el mundo, el cielo, el día"126. A su violento impulso se sublevan las profundidades marinas -"De Amphítrite el palacio cavernoso"-, elevando "diáfanos montes" de espuma que el mar absorbe con su "cerúlea boca" de cristal. El "monte de agua", imagen tomada de Virgilio que recorre la descripción de la tormenta ${ }^{127}$, domina la pintura del oleaje (I. 97):

Bolcán de plata, que a la ardiente llama, con que el Bóreas el vientre le alimenta, preñado del ardor en que le inflama, por bocas mil intrépido rebienta:

cuanta concha, coral, ova, y escama guardó en sus lamas, al impyreo avienta, siendo la nieve, que en sus ondas riza, de espuma cana cándida ceniza.

Los versos del latino reverberan en la escena del barco que se hunde -"Quéxanse al desprenderse con cruxidos / del vaso fatigado los fragmentos; / pero no es mucho, no, que den gemidos, /...a las tablas los naúfragos asidos, / mezclan sus quexas con espuma, y vientos"-, así como en esta visión de la flota maniobrando en el temporal, rematada a la manera de Góngora: "Ceden al temporal, baxos trasiegan/...se despegan / de tanta Syrte, que irse a pique afianza: / viran a un lado, y otro, y no

125 Compárese I, 94 con Eneida, I, 52 ss. En la Mexicana (II, 5) Neptuno excita al mar clavándole su tridente.

126 Véanse Eneida, I, 102-105 y sus paralelos en la Araucana (XV, 68, 75, donde se usa el nombre griego de Bóreas) y la Mexicana (II, 7).

127 Cf. Eneida, I, 105. Más adelante (I, 99) los "montes de agua" coronados de espuma son "moncayos", símil barroco a partir de la etimología "monte cano y nevoso" ya alegada por MARCiAL (Epigramas, I, 49: senemque Caium nivibus). La imagen reaparece en los combates en la laguna de Tenochtitlán (XII, 51): "Apolo se admiró desvanecido, / hallando el ponto convertido en monte; / y a no tener el curso tan sabido, / le sucede lo que antes a Faetonte". 
sosiegan /...y cuando entre las Scilas no se ahogan, / en Vergas nadan, y en Ovenques bogan"128.

Cambiando de asunto, la breve referencia en la crónica de Solís a los espectáculos y festejos con que fueron agasajados los españoles a su llegada a Tenochtitlán, permite recrear un famoso topos de la épica culta: los juegos en honor de Ascanio, donde Virgilio imitaba, a su vez, aquellos de Patroclo cantados por Homero ${ }^{129}$. Ruiz de León se distancia del latino no sólo sustituyendo algunas pruebas deportivas, sino por la atención al "vistoso aparato de sus arreos" y los "caracteres amatorios", según anticipa en el argumento de este Canto VII. En efecto, las "solemnes justas que al uso de su nación" organizara Moctezuma constituyen, en realidad, un gran espectáculo barroco, donde se suceden pompas y fanfarrias, danzas, mitotes, acrobacias, desafíos, lances venatorios y combates de gladiadores, todo ello en el marco de una arquitectura efímera, el circo levantado para la ocasión en la plaza del Templo Mayor.

Las referencias grecolatinas sirven, de nuevo, para magnificar el escenario -"No vio otra vez Tarpeyo en sus verdores, / no vio otra vez Symoente en sus riveras / palestra tan sobervia a sus cursores, / circo tan opulento a sus pantheras" (31)- y la tramoya de estos juegos: "Pudo el Gordiano, consiguió el Tarquino, / arrebatar el nombre de gloriosos, / con las máchinas grandes, que previno / su sobervia, a espectáculos famosos: / llegó de Domiciano, el peregrino / amphiteatro, a exceder los sumptuosos; / más ninguno tocar a la grandeza, / que en lo sumo que acaban, ella empieza" (32). Con la misma intención se afirma que "el cursor mexicano desafía / en la velocidad, y en la arrogancia, / a Troya el modo, a Roma la substancia”, y paradigmas míticos encarecen la crueldad de los luchadores (94): "No de Licaón en bárbaro Lyceo, / instruidos, más hicieran, cuando rudos / de aquella escuela que cursó Broteo, / salen de aquí sin ella más agudos". Y, en fin, la nomenclatura de los ludi romanos se aplica a los gladiadores aztecas (95): "Ni el Trace cruel podrá desde hoy ufano / jactar, pues quiso por Lanista fiero / vestir el Mirmillonio, que a la mano / llegó a embotar ofensas al aze-

128 Compárese, sucesivamente, I, 104, 105 con Eneida, I, 87 (Insequitur clamorque virum stridorque rudentum) y VII, 301 s. (Quid Syrtes aut Scylla mihi... profuit?).

129 En Historia de la Conquista, III, 18. Respecto a las fuentes clásicas, cf. Iliada, XXIII, 260 ss.; Eneida, V, 103-603. Sobre la versión de ERCILla (Araucana, X, 11-XI, 31), véase V. CRISTóbAL, art. cit., pp. 89-91. 
ro", resultando igualmente impropia la mención entre la fieras de una "Hircana Tigre" (88) y un "león de Libia" (90).

Respecto al programa, las regatas y concursos poéticos romanos quedan descartados "por remotos, por estraños": "Ni las naumachías con que Agripa, y Neró; / con góndolas de nácar algún día, / en el álbula undoso placentero / fueron Nereydas de su plata fría: / ni los scénicos juegos, que primero / corrió el etrusco por floresta umbría"130. Por otra parte, pese a que, según el poeta, fueron hechos a imitación de "los antiguos juegos pytios y nemeos" de los primeros sólo queda el "pregón sonoro en honor de Apolo" -aquí atribuido a Filipo de Macedonia-, así como el "laurel" de la victoria, y las "orlas de Apio" que premiaban a los campeones, en los segundos ${ }^{131}$.

Por otra parte, a diferencia del carácter funerario de los juegos antiguos, los mexicanos se desenvuelven en una atmósfera costumbrista de erotismo -los galanteos entre los campeones y las bellas espectadoras-, y, a la vez, simbólico: no en vano el heraldo de las justas es "...un alado niño, / retrato del que en Chipre fue incendiario", quien saluda al soberano "Con cortas voces, (porque es estatuto / del Lacón aprendido)". En efecto, con estos fastos Moctezuma intenta apaciguar a Cortés y ganarse su benevolencia, según él mismo aclara usando la mitología: "Ya que Marte sossiega al blando arrullo / de Venus... / no ha de gozar Adonis del reposo, / sin ser, para mí, más poderoso”. Y en su ansia por agradar al extranjero actúa "Cual suele hacer favorecido amante, / a quien de Antheros une la cadena, / excesos que demandan lo galante, / que son más siempre, que la dama ordena". El símil reaparece en la presentación del héroe: "Cortés, y qué gallardo que ha salido / sobre ante fino viste acicalado / peto de azero, que gentil ha unido / aire galán, a traje de soldado: / del morrión a la bota, le han pulido / Marte, y Adonis..."Y, sin embargo, bajo esta donosura los atemorizados aztecas siguen vislumbrando el "retrato de Marte"132.

130 VII, 12. Ambas pruebas abren y cierran los juegos de la Eneida (V, 133 ss., 600 ss., respectivamente), episodio donde intervienen las Nereidas (v. 239); además, Virgilio usa "Álbula", el nombre antiguo del Tíber, en III, 332.

131 Cf. VII, 7, 21 (Píticos), 26 (Nemeos). El "apio" y el "pino" de los ístmicos concurren en la estrofa 31, y más adelante (94) aparece el "acebuche", con el cual se tejían las coronas de los juegos olímpicos. Todos ellos comportaban agones musicales y carreras de carros ausentes en la Hernadia.

132 Pasajes citados: VII, 3, 15 (Moctezuma), 19-20 (Cupido), 53, 96 (Cortés). 
No es necesario insistir sobre el lugar central de la materia bélica y particularmente de las batallas en la epopeya, sobre todo en los poemas de asunto histórico, como esa Conquista de México que Ruiz de León parangona con las Guerras Médicas (I, 91) ${ }^{133}$ :

No cuente Athenas como acción estraña, que venciessen diez mil, con ossadía, a trescientos mil persas, que en campaña, en la batalla maratonia havía: si es uno para treinta, no es hazaña: ésta sí es admirable bizarría, pues a cada uno la India dio valiente, a dos millones, y sobró la gente.

En la Antigüedad, el relato militar llegó a configurar un genus historiográfico a cuya formalización contribuyó no poco la preceptiva retórica ${ }^{134}$. Las batallas de la épica culta, por su parte, responden a la tipología de la Ilíada, que Virgilio consagra para la posteridad en la segunda parte de la Eneida, y Ercilla inaugura en la tradición hispana ${ }^{135}$. Pasando a la Hernandia, la persistencia de este esquema narrativo es evidente en las fórmulas de encuadre, por ejemplo, del segundo choque entre los ejércitos español y tlaxcalteca, que abre el anuncio "Despierta a Marte militar estruendo / de timbales; antaras, y clarines; / ambos campos se avistan, pretendiendo / convertir en claveles los jazmines", y cierra un símil de regusto clásico: el campo de batalla cubierto de cadáveres cual sementera arrasada por las langostas ${ }^{136}$. En cuan-

133 El motivo reaparece en XI, 13 s.: "Assombro fue, cuando movida el Asia, / dio Xerxes sobre Grecia, tres millones / de soldados, por quienes quanto espacia / el Athos, transminó sus farellones... // Grandeza, sí, pero es más numerosa / la multitud, que el mexicano embía /...quien si apostara al mar, hombres, apenas / pudieran igualarlos sus arenas".

134 Así, Teón, Progymnásmata, 119: “...examinaremos primero los antecedentes de la guerra, las levas de tropas, los gastos, los temores, la devastación del país, los asedios; a continuación las heridas, las muertes, los duelos; y, en último lugar, la conquista y la esclavitud de los unos, y la victoria y los trofeos de los otros".

135 Sobre el modelo homérico, además de la monografía de BERNARD FENIK, Typical battle scenes in the Iliad, Steiner, Wiesbaden, 1968, véase MARK W. EDWARDS, "Homer and the oral tradition: The type-scene", OT, 7 (1992), 299-303. Respecto a la influencia de los relatos militares de la Araucana en la épica colonial, véase Piñero, art. cit., pp. 181-182.

${ }^{136}$ Cf. III, 46, 51. El símil de la siega remite, en última instancia, a Ilíada, X, 67 ss.; Ruiz de León parafrasea el virgiliano "enjambre de abejas" (Eneida, 
to al núcleo del relato, Ruiz de León sigue los pasos de Homero y Virgilio, quienes a diferencia de Lucano atienden menos a los movimientos de tropas que a los desafíos entre campeones y los triunfos individuales (aristeíai). En consecuencia, las batallas de la Hernandia se articulan como una sucesión de hazañas tanto del protagonista y otros capitanes españoles, cuanto de sus adversarios.

Así ocurre en la toma de Potochán en Tabasco, cuando tras las heroicas acciones de Carrasco y Portocarrero, "A lo más apretado del combate, / la espada llega, que Mavorte embidia, / y en el puño de Hernando se rebate /...del furor, que en su pecho oculto late, / testigo hace del indio la perfidia, / tan ágil al herir, que cercenando / solamente cabezas va segando" (II, 53). Mas entre las batallas de la Conquista de México, la primacía corresponde a Otumba: "No vio en sus Theatros Marte igual campaña", dice el poeta y resalta cómo en su transcurso "una proeza anega otra proeza", ya que si los mexicanos intentan "...con gentil desembarazo, / rendir al mismo Marte, brazo a brazo", los españoles compensan su desventaja emulando al "humano Marte" que los ha convocado a "vencer o morir"137. En consonancia con el fragor de la batalla, semejante a una tormenta o a la erupción de un volcán -"Así los unos, y otros, valerosos / sembrando muertes, destrozando vidas, / desfogan con incendios pavorosos / Etna mayor en llamas repetidas"-, Cortés es "el español Vesubio" que "cual con la espada, rayo del Tonante, / lo que delante ve, deja abrasado" 138 .

El imaginario, aderezado con exempla mitológicos e históricos, concurre en la descripción de los combates en torno la capital, previos a su rendición ${ }^{139}$. Ante la dureza del envite, Cortés demuestra su pundonor: "Bolvió a nacer el Fénix de sí mismo, / y también el caudillo al lucimiento; / que el valor del que es grande en tal abismo, / hace como Titán su nacimiento". Pero

I, 430 ss.) a propósito de "la fragua de Vulcano" donde los españoles construyen armas y navíos para la toma de la Capital (XII, 12).

137 Pasajes citados: XI, 16, 26-28, 18-19.

138 Véanse XI, 18 ss., y en concreto 21, 23 (volcanes) y 26, 28 (rayo de Júpiter). Para la bravura de Eneas, Virgilio acude al fuego y los fenómenos celestes: por ejemplo, en el duelo con Turno sus armas resuenan como los truenos en las altas cumbres del Atos, el Érix o el Apenino (Eneida, XII, 697 ss.).

139 Cf. XII, 28 ss. La estrechura de la laguna recuerda "la azul campaña de Anfitrite, /...quando el pagano, sin hallar desquite / su locura, lamentó anegadas / en undoso sepulcro, con espanto, / quillas, que assombro dieron a Lepantho" (XI, 29). 
en medio de la lid cae herido su caballo, "Xantho andaluz... / Y su Aquiles el golpe previniendo / al espirar aqueste, promptamente / se dexó caer sobre la propia gente". La circunstancia es aprovechada por un enemigo, "Anteón indiano Telpochs, cuya frente / tanto eleva su bárbara estatura, / que domina las picas de su gente; /...con él se abraza tan resueltamente, /...que el triunfo consiguiera su deseo, / si entre sus brazos no estuviera Alceo". Y como en el episodio mitológico aludido, el héroe civilizador derrota al bárbaro gigante: "Cimbra al jayán, restituyendo al viento, / del penacho las plumas que reparte, / y a la tierra aquel monte sin aliento: / por Hércules le tienen, o por Marte"140. Más adelante, el recuerdo de guerreros antiguos engrandece a los aztecas muertos en la batalla, caso de Ninatón, "indiano Cinegiro", y de Cletl, considerado superior al ateniense Conón y los romanos Camilo y Decio ${ }^{141}$.

Por lo demás, la impronta del mantuano en la Hernandia es manifiesta en dos componentes característicos de las batallas épicas: los símiles referidos al mundo animal y las descripciones de la masacre. Así, mientras en Tabasco los españoles luchan como "lobos" y "tigres" contra los mayas asediados en Potonchán, como antes hicieran los troyanos, en Otumba el ataque al portaestandarte azteca, cuya muerte otorga la victoria, se representa en términos cinegéticos: el noble azteca primero figura un tigre feroz "de armas y canes acosado... en las hircanas selvas", y luego deviene "Qual las arenas de la Libia ardiente / bramando ciego surca con pie hendido, / manchada a esmaltes de carmín caliente, / su rugosa cerviz, toro prendido" 142. Para terminar, como ilustración de los desastres de la guerra, donde se aúnan herencia clásica y sensibilidad barroca, valga el detallismo de estas heridas mortales (II, 52): "A Tetonón intrépido Carrasco, / haciendo vanidad de sus excessos, / tan recio lo estrelló contra un peñasco, / que en él la frente le estampó, y los sesos: / y como los mostachos con el casco / allí quedaron,

140 XII, 47, 48, 50-52. En la tradición antigua (por ejemplo, PsEudoEurípides, Reso, vv. 185 ss.; Diodoro de Sicilia, VI, 3) Janto, el caballo de Aquiles, pasa por inmortal.

141 Cf. XII, 68, 103-104. El valor de Cinegiro, el hermano de Esquilo caído en Maratón (HeRódoto, VI, 114) devino proverbial.

142 Pasajes citados: II, 47; XI, 29-32. El símil del lobo aparece en la Eneida, II, 355 ss.; IX, 59 ss.; y en X, 453, la lucha del león y el toro, imitada por nuestro poeta en X, 122. Sobre el imaginario animalesco de Virgilio, véase Ángela Palacios Martín, "Turno y Eneas a través de los símiles de la Eneida", AEF, 2 (1979), 191-209. 
sin chorrear, impressos, / lo sacó tan al vivo, que su cara, / con un pincel mejor no la pintara"; y ésta otra octava inserta en la campaña de Tlaxcala (III, 50) ${ }^{143}$ :

Trúncanse las cabezas, y costillas; córtanse piernas, púrpura vertiendo; hiéndense espaldas, pártense en hastillas, para matar a precio de ir muriendo: brotan cráneos, pulmones, y ternillas, al martillar de tanto golpe horrendo; más pulsación en ados tan esquivos hallaron entre muertos, que entre vivos.

\section{Consideraciones finales}

Una vez concluido este periplo por la Hernandia, siguiendo las huellas de la Antigüedad en el contexto a priori exótico y anacrónico de la Conquista de México, es hora de recapitular. El componente clásico se constata, a primera vista, en el vocabulario: ya los cultismos que contribuyen al decorum, la dicción elevada y solemne requerida por el tema y el género, ya los epítetos caracterizadores de personajes, lugares e instituciones. Mayor relevancia cabe otorgar a las comparaciones, símiles y metáforas, donde la historia y los mitos de Grecia y Roma devienen paradigmáticos. En ambos casos, Ruiz de León, uno de los últimos culteranos del México colonial, recreó tópicos de amplio recorrido en la poesía, lo cual no implica ignorancia de los modelos grecolatinos. Así que la imaginería mitológica estuviese ya elaborada en los autores clásicos españoles y en tratados mitográficos, no eximía, a un poeta erudito, del manejo de Ovidio. Es más, tanto el contexto histórico-literario cuanto los resultados de este estudio hacen insostenibles asertos como que "de Virgilio no aprendió Ruiz de León más que las palabras tradicionales del comienzo" 144 ; y, sin embargo, no resulta fácil discernir cuándo la Hernadia se mira en el de Mantua y cuándo éste reverbera a través de la espesura intertextual. En efecto, según la lógica de la mímesis, el diálogo con los antiguos podría haberse esta-

143 Además de las cruentas escenas de la numantina "Noche triste" (X, 112 ss.), véanse II, 54-55; III, 49; VII, 87, 89; XI, 36.

144 Frank D. Dauster, Breve historia de la poesía mexicana, Eds. De Andrea, México, 1956, p. 50. 
blecido por vías directas, intermediadas o por ambas a la vez, lo que invita a ser cautos al identificar las autoridades de cada pasaje. Por ejemplo, parece incuestionable la raigambre clásica de las manifestaciones del prólogo acerca de la épica, el poeta y su arte. Sin embargo, frente a una supuesta dependencia de Luzán y Feijoo sería preferible hablar, en relación con la preceptiva de género, del aristotelismo común en el siglo y de la teoría neoplatónica sobre la inspiración derivada de las poéticas postrenacentistas $^{145}$.

Por otra parte, el juicio crítico según el cual Ruiz de León se limitó a poner en verso la Historia de Solís, requiere ser matizado. Sin negar la preeminencia de este historiador, el análisis contextualizado de los temas clásicos indica el manejo puntual de otras crónicas del descubrimiento y de la Conquista, así como la importancia en los episodios de materiales aportados por la poesía, no sólo la épica de Virgilio y de los primeros cantores de Cortés, sino también la gran lírica del barroco español y novohispano. Recordemos que Ruiz de León -un poeta aficionado que aspiraba a mejorar de empleo ganándose el favor de un círculo de eruditos y hombres poderosos- publicó la Hernandia con más de sesenta años, vertiendo en ella "la cultura literaria acumulada a lo largo de una vida dedicada al cultivo de las bellas letras" 146 . Por lo tanto, acertaba Juan de Buedo Girón, al señalar en sus Octavas jocoserias ${ }^{147}$ :

Pues si los doctos, y la gente lega toman a Ruiz León en una mano, en otra a Garcilaso, y Lope Vega, y en otra al Solís, nuestro mantuano: y en fin, si a tomar tantos poetas llega, que se haga cada pobre centimano, ¿no dirá, sin que a nadie haga desdoro, que su Hernandia es también del Siglo de Oro?

145 Al respecto, véase JoAQuín Roses Lozano, "Sobre el ingenio y la inspiración en la edad de Góngora”, Criticón, 49 (1990), 31-49. Según FABbri ("La Hernandia...", pp. 371 ss.) Ruiz de León manejó la Poética de Luzán (opinión compartida por YAGÜE BoCH, art. cit., p. 259) y añade que sus "raptos de la mente" (I, 12) están inspirados en los de Feijoo.

146 Así dice M. Peña ("Luces dieciochescas...", p. 123), parafraseando a Beristáin.

${ }^{147}$ En la estrofa sexta (hoja sin numerar de los preliminares). Sobre la atribución de la Hernandia a Buedo, véase supra, nota 35. 
Pero el tratamiento de nuestros tópicos, además de un proceso creativo en el cual los modelos clásicos se acrisolan en una intrincada trama de referencias intertextuales, pone de relieve una determinada cosmovisión ideológico-religiosa en cuyo interior se valora la cultura grecorromana. Significativo, al respecto, es el doble rasero utilizado en comparaciones y símiles: en el caso de los mexicanos, lo clásico funciona como un código interpretativo de cosas americanas, nuevas y extrañas a la mirada europea, o bien sirve para, magnificando al "bárbaro" vencido, encumbrar de rechazo a los conquistadores; mas cuando Cortés u otro español son el contrapunto, los generales famosos, los dioses y los héroes resultan sistemáticamente degradados, al tratarse de paganos y falsas divinidades cuyo poderío, al igual que el periclitado imperio de Moctezuma, cayó ante el signo de la cruz. El menosprecio implícito en los exempla manifiesta la desconfianza de la contrarreforma hacia la cultura grecorromana, con la importante excepción de Aristóteles, convertido por el escolasticismo en "martillo de herejes" como lúcidamente analizó Feijoo ${ }^{148}$. Por ello, Ruiz de León construye su ideal de heroísmo sobre la ética del Estagirita, aderezada por los comentaristas barrocos con las dosis pertinentes de estoicismo cristiano.

En conclusión, la Antigüedad aportaba prestigiosos oropeles para el reverdecer de las ajadas coronas del imperio español que pretende la Hernandia, "la fachada ornamental ultrabarroca y posbarroca de un edificio cuyos interiores se desmoronaban a ojos vistas" 149 .

Minerva Alganza Roldán

Universidad de Granada

148 Véase "Méritos y fortuna de Aristóteles y sus escritos", en Teatro crítico universal, t. 4, discurso VII.

149 En palabras de M. PeñA, “Luces dieciochescas...”, p. 124. 